\title{
1 Strontium isotopes reveal diverse life history variations, 2 migration patterns, and habitat use for Broad Whitefish 3 (Coregonus nasus) in Arctic, Alaska
}

Jason C. Leppi ${ }^{1,2}$, Daniel J. Rinella ${ }^{3}$, Mark S. Wipfli ${ }^{4}$, Randy J. Brown ${ }^{5}$, Karen J. Spaleta ${ }^{6}$, Matthew S. Whitman ${ }^{7}$

${ }^{1}$ Alaska Cooperative Fish and Wildlife Research Unit, College of Fisheries and Ocean Sciences, University of Alaska Fairbanks, Fairbanks, Alaska, United States of America

${ }^{2}$ Research Department, The Wilderness Society, Anchorage, Alaska, United States of America

${ }^{3}$ Fish and Wildlife Field Conservation Office, U.S. Fish and Wildlife Service, Anchorage, Alaska, United States of America

${ }^{4}$ U.S. Geological Survey, Alaska Cooperative Fish and Wildlife Research Unit, Institute of Arctic Biology, University of Alaska Fairbanks, Fairbanks, Alaska, United States of America

${ }^{5}$ U.S. Fish and Wildlife Service, Fairbanks Fish and Aquatic Conservation Office, Fairbanks, Alaska, United States of America

${ }^{6}$ Alaska Stable Isotope Facility, Water and Environmental Research Center, Institute of Northern Engineering, University of Alaska Fairbanks, Fairbanks, Alaska, United States of America

${ }^{7}$ Arctic District Office, Bureau of Land Management, Fairbanks, Alaska, United States of America

ORCiD: JCL (0000-0002-6970-6402), DJR (NA), MSW(0000-0002-4856-6068), RJB (NA), KJS (0000-0002-7907-201X), MSW (0000-0001-5106-0810)

* Corresponding author

E-mail: jcleppi@alaska.edu; jason leppi@tws.org (JCL)

\section{Short title: Broad Whitefish (Coregonus nasus) life histories in Arctic, Alaska}

Keywords: Arctic; subsistence; Whitefish; Colville River; conservation; microchemistry; otolith; life history strategies

This draft manuscript is distributed solely for purposes of scientific peer review. Its content is deliberative and predecisional, so it must not be disclosed or released by reviewers. Because the manuscript has not yet been approved for publication by the U.S. Geological Survey (USGS), it does not represent any official USGS finding or policy. 
Leppi et al. PLOS ONE 27 October 2021

\section{Abstract}

Conservation of Arctic fish species is challenging partly due to our limited ability to track

37 fish through time and space, which constrains our understanding of life history diversity and lifelong habitat use. Broad Whitefish (Coregonus nasus) is an important subsistence species for Alaska's Arctic Indigenous communities, yet little is known about life history diversity, migration patterns, and freshwater habitat use. Using laser ablation Sr isotope otolith microchemistry, we analyzed Colville River Broad Whitefish ${ }^{87} \mathrm{Sr} /{ }^{86} \mathrm{Sr}$ chronologies $(\mathrm{n}=61)$ to reconstruct movements and habitat use across the lives of individual fish. We found evidence of at least six life history types, including three anadromous types, one semi-anadromous type, and two nonanadromous types. Anadromous life history types comprised a large proportion of individuals sampled (collectively, 59\%) and most of these (59\%) migrated to sea between ages samples and entered marine habitat as larvae. Nonanadromous life history types comprised the remainder (collectively, 13\%). Otolith ${ }^{87} \mathrm{Sr} /{ }^{86} \mathrm{Sr}$ data from juvenile and adult freshwater stages suggest that habitat use changed in association with age, seasons, and life history strategies. This information on Broad Whitefish life histories and habitat use across time and space will help managers and conservation planners better understand the risks of anthropogenic impacts and help conserve this vital subsistence resource.

\section{Introduction}

57 extinction [1-4]. Freshwater ecosystems cover less than $1 \%$ of the global surface but support about half of the 30,000 described fish species [5]. Consequently, environmental impacts on 
Leppi et al. PLOS ONE 27 October 2021

59 freshwater ecosystems can have a disproportionate effect on interspecific and intraspecific fish

60 diversity [6-8]. Arctic freshwater ecosystems are no exception and recent assessments confirm

61 that ongoing climate-driven changes [9] threaten Arctic freshwater biodiversity [10].

62 The accelerated impacts of climate change at high latitudes $[11,12]$ are a major threat to

63 Arctic freshwater ecosystems [13], altering streamflow [14-17], warming [18,19] and drying

64 [20] aquatic habitats; causing eutrophication [21] and browning of lakes [22,23]; and allowing

65 for northward range expansion of eurythermic species [24]. To a lesser extent, long-range

66 pollution [7], habitat loss and degradation, and flow modification from oil and gas development

67 [25] can occur independently or interact with climatic change to alter Arctic freshwater

ecosystems [26]. New regional and global emerging threats, such as invasive species [27],

69 diseases, or algal blooms [28] may add additional stress to ecosystems [7], potentially reducing

70 genetic and life history diversity within populations and further accelerating biodiversity loss

$71 \quad[29-31]$.

Understanding lifelong habitat use for Arctic fishes is challenging due to their high

73 mobility and our limited ability to track fish as they move among a suite of habitats (i.e.,

74 foraging, overwintering, spawning) that are geographically dispersed, change over time, and are

75 often temporary [32]. As a response to dispersed resources and constantly changing conditions,

76 Arctic fish populations have developed numerous life history strategies to exploit food resources,

77 seek refugia from harsh environmental conditions [33], and maximize reproductive success and

78 survival $[34,35]$.

Foraging strategies include ontogenetic or seasonal movements to marine habitats [36-

39] but, due to extreme winter conditions, fish must leave productive marine habitats and find

81 overwintering refugia in freshwater or brackish habitat to avoid lethal low temperatures [40]. An 
Leppi et al. PLOS ONE 27 October 2021

82 iteroparous reproductive strategy is typical for fishes that use habitats with high environmental

83 variability $[41,42]$ and, when coupled with a longer life, it hedges against unpredictable conditions [43]. The proximity of safe rearing habitats at or downstream of spawning areas also

85 helps to facilitate juvenile survival $[44,45]$ and, for anadromous fishes, a diversity of age at ocean entry helps to buffer the effects of unfavorable conditions [29]. This diversity in life

87 history facilitates long-term population stability, helping to stabilize ecosystems and buffer populations from environmental perturbations that may reduce habitat quality and increase mortality [46-48]. habitat use within and across life stages in Arctic populations, but previous research in other parts of its range supports the theory of a highly mobile species that utilizes various aquatic habitats [50-52]. Broad Whitefish reach sexual maturity around the age of eight but can live 30 or more years [49]. Habitat use across time and space likely results in a variety of life histories with varying amounts of time spent in freshwater, estuarine, and marine habitats [38,53]. Broad

97 Whitefish larvae are thought to be passively advected downstream to deltas, estuaries, and nearshore areas by spring breakup flows, based on their hatch timing, inability to resist spring streamflow as larvae, and general abundance in coastal and estuarine habitat [54-57]. Referred to as Aanaakliq in the Iñupiaq language, Broad Whitefish, are valued due to their relatively large

101 size (up to $4.5 \mathrm{~kg}$ ) and abundance during migrations [58,59], accounting for about half the total 102 mass of fishes harvested across all Beaufort Sea communities [60]. However, without information on life history diversity and habitat use, land and resource managers lack essential 104 information for the management and conservation of this important subsistence fish. 
Leppi et al. PLOS ONE 27 October 2021

Otolith microchemistry is an effective tool to understand life history diversity and habitat use of fishes [51,61-66]. Otoliths, paired inner ear stones used for hearing and balance in all teleost fishes, are laid as concentric layers of metabolically inert biogenic minerals, primarily calcium carbonate. Elements are permanently incorporated into their organic matrix, and compositional changes across the layers reflect changes across an individual's life [67].

Strontium (Sr), a naturally occurring element derived from geologic material, has four stable isotopes $\left({ }^{88} \mathrm{Sr},{ }^{87} \mathrm{Sr},{ }^{86} \mathrm{Sr},{ }^{84} \mathrm{Sr}\right)$, in which only ${ }^{87} \mathrm{Sr}$ is radiogenic. The ratio of ${ }^{87} \mathrm{Sr}$ to ${ }^{86} \mathrm{Sr}$

$112\left({ }^{87} \mathrm{Sr} /{ }^{86} \mathrm{Sr}\right)$, which roughly has similar proportions of elemental $\mathrm{Sr}$ and can be measured at similar 113 precisions, reflects Sr released into freshwater sources (e.g., rivers, lakes, streams) and is driven 114 by differences in lithology, age, chemical composition [68-70], and weathering rates of surficial 115 geology [71-73].

Fish take up dissolved $\mathrm{Sr}$ through the gills, and the $\mathrm{Sr}$ isotopes are incorporated into the

117 otolith matrix $[67,74]$, forming a continuous record of $\mathrm{Sr}$ isotope values that directly reflects 118 habitats inhabited across an individuals' life[75]. Compared to freshwater habitats, ${ }^{87} \mathrm{Sr} /{ }^{86} \mathrm{Sr}$ in 119 marine habitats are generally lower, homogenous, and constant due to the long residence time 120 and mixing of oceans [71]. The concentrations of total $\mathrm{Sr}$ and ${ }^{88} \mathrm{Sr}$, the most abundant of the four 121 stable isotopes and a reliable proxy for total Sr, increase with water salinity and are consistently 122 higher in marine versus freshwater habitats. For diadromous fishes, these relative differences in 123 Sr isotopes can be used to indicate the timing and duration of freshwater, estuarine, and marine 124 habitat use $[38,76]$. 
Leppi et al. PLOS ONE 27 October 2021

128

129 147 habitats.

\section{Materials and Methods}

are both likely essential for egg survival [49]. Due in part to its watershed size, the Colville River also has the largest delta on the Alaskan Beaufort Sea coast, which provides abundant rearing habitat for larval and juvenile fishes [79]. Broad Whitefish can live for 30+ years, and they return to the Colville River ecosystem regularly to reproduce [59], likely migrating from a variety of productive foraging areas in coastal lagoons and rivers across the Beaufort Coastal Plain. Thus, by sampling the Colville River's spawning run, we may be learning about life-history patterns of Broad Whitefish at the regional scale.

Conservation of freshwater fish diversity requires an understanding of lifelong habitat use. For many Arctic fishes, this information is lacking because movement between key habitats changes with age and life history strategy and is difficult to monitor. To fill important knowledge gaps about Broad Whitefish habitat use, we used $\mathrm{Sr}$ isotope $\left({ }^{87} \mathrm{Sr} /{ }^{86} \mathrm{Sr},{ }^{88} \mathrm{Sr}\right)$ otolith chronologies across individuals' lives to quantify life history attributes and reconstruct migration patterns of migrating fish captured within the Colville River, Alaska. Our specific objectives were to (i) document the range of life history types and explore how individuals are distributed among several predefined life history types, (ii) determine the proportion of Broad Whitefish that are anadromous and investigate the timing of marine habitat use, and (iii) determine if freshwater natal and freshwater juvenile rearing region ${ }^{87} \mathrm{Sr} /{ }^{86} \mathrm{Sr}$ remain constant across life history groups. Understanding the diversity of lifelong habitat use will provide managers and conservation planners essential information to begin to understand Broad Whitefish exposure to changing 
Leppi et al. PLOS ONE 27 October 2021

The Central Beaufort Sea region study area (Fig 1) contains a diversity of fish habitats.

152 Situated between the Ikpikpuk and Canning rivers in Arctic Alaska, the coastline is a spectrum of

153 bays and inlets, tapped basins (basins that are breached by the sea due to erosion), lagoons

154 behind barrier islands, and exposed bluffs [80]. River deltas are frequent along the coast, the size

155 varying based on physiography and watershed size [80]. Thermokarst and riverine lakes that vary

156 in size, depth, and connectivity $[81,82]$ cover $30 \%$ of the region's surface area [83]. Stream

157 habitats vary by watershed and geomorphic setting [84,85], resulting in colluvial channels in

158 foothill and mountainous headwaters, beaded headwater streams in low-gradient coastal plains,

159 and meandering alluvial streams and rivers lower in watersheds [82]. Geologic lithology

consists of materials from Precambrian and Paleozoic fragments and continental margin

materials dating to the Cretaceous period [68]. Modeled ${ }^{87} \mathrm{Sr} /{ }^{86} \mathrm{Sr}$ are estimated to be highest in

areas of intrusive mafic and ultramafic lithologies, and lowest near the coast (ca. 0.7070) within

marine and eolian deposits [69]. Modeled stream ${ }^{87} \mathrm{Sr} /{ }^{86} \mathrm{Sr}$ tend to be higher in watersheds that during transport [86].

Fig 1. Study area. The Central Beaufort Sea region in Arctic Alaska, situated between the

172 Ikpikpuk and the Canning River, AK, contains a diversity of aquatic habitats. The large Colville

173 River, AK, USA (ca. watershed area $60,000 \mathrm{~km}^{2}$ ), located in the middle of the Central Beaufort

174 Sea coast, AK, contains minor tributaries that drain from the Brooks Range, AK (thin grey lines) 
Leppi et al. PLOS ONE 27 October 2021

175 and main tributaries (thick dark grey lines) that flow toward a large delta on the edge of the

176 Beaufort Sea, near the community of Nuiqsut, AK. We collected fish at three sites (black

177 triangles) within the Colville River (site 1= Itkillik, site $2=$ Puviksuk, site $3=$ Umiat).

The region's stark seasonality can be divided into two main seasons, cold and warm, but the 
Leppi et al. PLOS ONE 27 October 2021

26, and at Itkillik on October 10-11. We euthanized captured Broad Whitefish and recorded fork length $(\mathrm{n}=97$, all of which were adults $\geq 42 \mathrm{~cm}$; [49]), total weight, gonad weight, and sex (44 males, 47 females, 7 undetermined; S1 Table). We collected sagittal otoliths from all individuals using the Guillotine method [89], rinsed in water, and stored in paper envelopes (Table 1). The planned sample size of 50 individuals per site was smaller than anticipated at Umiat $(\mathrm{n}=23)$ and Itkillik $(n=17)$, as opposed to Puviksuk $(n=57)$, due to unexpectedly high streamflow at the former and an early freeze-up at the latter that inhibited our ability to capture fish.

Table 1. Summary of otoliths collected from Broad Whitefish (Coregonus nasus) caught in the Colville River, AK, USA.

\begin{tabular}{|c|c|c|c|c|c|c|c|}
\hline $\begin{array}{c}\text { Capture } \\
\text { Location }\end{array}$ & $\begin{array}{c}\text { Month } \\
\text { Caught }\end{array}$ & $\begin{array}{c}\text { Sample } \\
\text { Size (N) }\end{array}$ & $\begin{array}{c}\text { Male } \\
(\mathrm{N})\end{array}$ & $\begin{array}{c}\text { Female } \\
(\mathrm{N})\end{array}$ & $\begin{array}{c}\text { Mean Length } \\
(\mathrm{mm})\end{array}$ & $\begin{array}{c}\text { Mean } \\
\text { Weight (g) }\end{array}$ & $\begin{array}{c}\text { Mean Age } \\
(\mathrm{yrs})\end{array}$ \\
\hline Puviksuk & July & 57 & 32 & 25 & 473 & 1292 & 17 \\
\hline Umiat & August & 23 & 12 & 11 & 551 & 2286 & 21 \\
\hline Itkillik & October & 17 & 8 & 9 & 547 & 2237 & 22 \\
\hline
\end{tabular}

We caught fish at three locations (Puviksuk, Umiat, Itkillik) in the Colville River, AK, USA. N = number of unique otoliths or individuals, $\mathrm{mm}=$ millimeters, $\mathrm{g}=$ grams, and $\mathrm{yrs}=$ years.

Fig 2. Otolith collection, laser analysis, and life history type classification. (A) Broad Whitefish (Coregonus nasus) from the Colville River, AK, USA (Photo credit: Jason C. Leppi) (B) Broad Whitefish otolith showing the core, annuli, and laser ablation path (Photo credit: Dan Bogan). (C) Flow diagram showing the life history supervised classification approach used to group Broad Whitefish.

\section{Sr isotope analysis of otoliths}


Leppi et al. PLOS ONE 27 October 2021

\section{Otolith preparation}

We mounted sagittal otoliths on individual microscope slides using Crystalbond ${ }^{\mathrm{TM}} 509$,

225 otoliths on petrographic slides $(2.7 \times 4.6 \mathrm{~cm})$ and repolished using $3-\mu \mathrm{m}$ alumina slurry. A total

227 numerical ID.

\section{Laser ablation}

We measured $\mathrm{Sr}$ isotope concentrations $\left({ }^{88} \mathrm{Sr},{ }^{87} \mathrm{Sr},{ }^{86} \mathrm{Sr},{ }^{84} \mathrm{Sr}\right)$ across a subset of the

232 instrument availability). We selected samples to prioritize for laser ablation with the goal of 
Leppi et al. PLOS ONE 27 October 2021

242 ensure that the freshwater natal region was identified, our ablation path encompassed the entire

243 first year of growth (Fig 2B) [63]. We performed an initial ablation cleaning using $80 \mu \mathrm{m}$ circle

244 spot size and $15 \mu \mathrm{m} / \mathrm{s}$ scan speed over the surface of otoliths prior to analysis. For isotope

245 analysis, the laser was set to $35 \mu \mathrm{m}$ beam diameter, a pulse rate of $10 \mathrm{~Hz}$, a speed of $5 \mu \mathrm{m} / \mathrm{s}$, and

246 a laser fluence of $6.64 \mathrm{~J} / \mathrm{cm}^{2}$. We mixed the laser stream with the output of an Aridus II ${ }^{\mathrm{TM}}$

247 membrane desolvation system via a mixing chamber immediately prior to the plasma inlet,

248 which allowed for optimization of the signal of the MC-ICP-MS and facilitated external intra-

249 elemental correction of the instrument isotope fractionation (IIF) [92]. We used a National

250 Institute of Standards and Technology $\left(\mathrm{NIST}^{\circledR}\right)$ solution of $\sim 13 \mathrm{ng} \mathrm{g}^{-1} \mathrm{SRM} 987\left(\mathrm{SrCO}_{3}\right.$ isotopic

251 standard) and $\sim 20 \mathrm{ng} \mathrm{g}^{-1} \mathrm{Zr}$ standard to optimize the instrument and also aspirated via the Aridus

252 II ${ }^{\mathrm{TM}}$ every 30 minutes for IIF correction via bracketing from standard to sample acquisition.

253 While we ablated samples, the Aridus $\mathrm{II}^{\mathrm{TM}}$ aspirated a $2 \%$ solution of $\mathrm{HNO}_{3}$ that was double

254 distilled via sub-boiling distillation (Savillex DST-1000) from trace metal grade concentrated

$255 \mathrm{HNO}_{3}$. We then used American Society for Testing and Materials (ASTM) Type I water from a

256 Milli-Q ${ }^{\circledR}$ IQ 7000 system, which had been further purified via a double sub-boiling distillation,

257 for dilution. Instrumental parameters used during laser ablation isotopic analysis are listed in the

258 S2 Table of the Appendix.

262 by subtracting the mean gas blank values obtained during the 30 -second laser-warmup period

263 prior to each ablation for all measured isotopes. We calculated calcium $(\mathrm{Ca})$ dimer $(\mathrm{CaCa})$ and

$264 \mathrm{Ca}$ argide (CaAr) corrections based on the blank corrected signals at mass to charge number ( $\mathrm{m} / \mathrm{z}$ 
Leppi et al. PLOS ONE 27 October 2021

$265=82$ and 83) using the natural abundances of $\mathrm{Ca}$ and argon (Ar) and applied to the blank

266

267

268

269

270

271

272

273

274

275

276

277

278

279

280

281

282

283

284

285

286

287 Statistical analysis

corrected signals at $\mathrm{m} / \mathrm{z} 84,85,86,87$, and 88 . We calculated rubidium $(\mathrm{Rb})$ interference

correction on m/z 87 using Russell's law via mass 85 and applied via peak stripping in which the fractionation of $\mathrm{Rb}$ was assumed to be equal to strontium $(\mathrm{Sr})$ due to the low levels of $\mathrm{Rb}$

naturally occurring in sample materials like otoliths. We corrected the ${ }^{87} \mathrm{Sr} /{ }^{86} \mathrm{Sr}$ ratio via standard/sample bracketing of the NIST SRM ${ }^{\circledR} 987$ solution. Instrumental isotopic fractionation (IIF) was corrected externally, also using the NIST SRM ${ }^{\circledR} 987$ solution.

\section{Otolith ${ }^{87} \mathrm{Sr} /{ }^{86} \mathrm{Sr}$ data post-processing}

We individually inspected strontium data from otolith laser ablation for data quality, trimmed, and adjusted accordingly. We removed otoliths from the dataset if Sr data contained unreliable values due to cracks $(n=8)$. We used a Leica ${ }^{\circledR}$ microscope with a micrometer to measure the length of the ablation path from age-1 dorsal side to the otolith edge on the ventral side (Fig 2B). We visually identified otolith core and annuli following standard methods [91] and measured the length of each annuli from the beginning of the ablation transect using a Leica ${ }^{\circledR}$ microscope with a micrometer. We then cropped cropped data in $\mathrm{R}$ statistical program (http://cran.r-project.org/), from the estimated otolith core to the edge, to facilitate comparison between otoliths. Finally, to facilitate classification we inspected strontium data for each otolith and made minor adjustments to the ratio data $\left({ }^{87} \mathrm{Sr} /{ }^{86} \mathrm{Sr}\right)$ to align them with the global marine value $(\mathrm{GMV}=0.70918 \pm 0.00006)$ when ${ }^{88} \mathrm{Sr}$ concentrations were above $12.26 \mathrm{~V}$ and ensure that non-elevated ${ }^{88} \mathrm{Sr}$ concentrations $(<12.26 \mathrm{~V})$ fell outside of this range. 
Leppi et al. PLOS ONE 27 October 2021

We used Generalized Additive Models (GAMs) to analyze the ${ }^{87} \mathrm{Sr} /{ }^{86} \mathrm{Sr}$ variation from each otolith core to edge. A GAM is an extension of a generalized linear model in which the linear predictor is provided by a user-assigned sum of smooth functions of the covariates, plus a conventional parametric component of the linear predictor [96]. We fit GAMs to each otolith ${ }^{87} \mathrm{Sr} /{ }^{86} \mathrm{Sr}$ profile using the MGCV package in $\mathrm{R}$, which is similar to previous methods used to analyze otolith ${ }^{87} \mathrm{Sr} /{ }^{86} \mathrm{Sr}$ of Slimy Sculpin (Cottus cognatus) [97] and Chinook salmon ${ }^{87} \mathrm{Sr} /{ }^{86} \mathrm{Sr}$ profile.

\section{Life history attributes and classification}

We visually compared the ${ }^{88} \mathrm{Sr}$ concentrations and ${ }^{87} \mathrm{Sr} /{ }^{86} \mathrm{Sr}$ across each otolith core-to-

309 (i.e., $2055 \mathrm{mg} / \mathrm{kg}$ ) by the average ${ }^{88} \mathrm{Sr}$ FEBs-1 standard value during ablation and multiplying by 
Leppi et al. PLOS ONE 27 October 2021

311 signal below $6.13 \mathrm{~V}$ (corresponding to ca. $850 \mathrm{mg} / \mathrm{kg}$ ) to be time spent in freshwater habitat, a

312 signal greater than $6.13 \mathrm{~V}$ and less than $12.26 \mathrm{~V}$ (corresponding to ca. $1700 \mathrm{mg} / \mathrm{kg}$ ) to be time

313 spent in estuarine water and a signal greater than $12.26 \mathrm{~V}$ (corresponding to ca. $1700 \mathrm{mg} / \mathrm{kg}$ ) to

314 be marine habitat use $[38,76]$.

We inferred occupied habitats and behaviors based on otolith ${ }^{88} \mathrm{Sr}$ concentrations and

${ }^{87} \mathrm{Sr} /{ }^{86} \mathrm{Sr}$ at different ages, determined by reading annuli and identifying important otolith

317 regions. We defined natal regions as areas distal to the core and without detectable maternal

318 strontium that had ${ }^{88} \mathrm{Sr}$ concentrations representative of freshwater and relatively constant

$319{ }^{87} \mathrm{Sr} /{ }^{86} \mathrm{Sr}$, which were assumed to precede the onset of exogenous feeding and downstream

320 migration to rearing habitat [99]. We defined freshwater juvenile rearing regions as all values

321 distal to the natal region, but before migration to marine habitats and prior to age-1(i.e.,

322 freshwater age-0 juvenile rearing period). We considered freshwater regions to be isotopically

323 distinct from each other, inferring movement to a different habitat, if the difference between

324 mean ${ }^{87} \mathrm{Sr} /{ }^{86} \mathrm{Sr}$ was $>0.00005$ [97]. This value was chosen because it was sufficiently greater

325 than the mean \pm 2 S.E. of all juvenile and natal region values and would be large enough to

326 detect differences $[62,97]$. For individuals that did not migrate to marine habitat at age- 0 , this

327 region encompassed all values during the growth period (identified as the opaque region with

328 wide growth bands) before the winter period [91]. We determined age at marine entry by

329 comparing ${ }^{88} \mathrm{Sr}$ concentrations and ${ }^{87} \mathrm{Sr} /{ }^{86} \mathrm{Sr}$ in relation to annuli and we assigned all anadromous

330 individuals with marine entry values (e.g., age-0, age-1) based on when the first maximum ${ }^{88} \mathrm{Sr}$

331 concentrations were above $12.26 \mathrm{~V}$ and ${ }^{87} \mathrm{Sr} /{ }^{86} \mathrm{Sr}$ were near the GMV.

We grouped individuals into six life history types using a supervised classification

333 approach. We considered individuals with otolith ${ }^{88} \mathrm{Sr}$ concentrations above $12.26 \mathrm{~V}$ and 
Leppi et al. PLOS ONE 27 October 2021

${ }^{87} \mathrm{Sr} /{ }^{86} \mathrm{Sr}$ near the GMV anadromous, and we considered all other individuals as nonanadromous

$[38,51,63]$. We classified anadromous individuals into four subgroups based on the type of

rearing habitat inhabited at age- 0 and duration in fresh water prior to marine entry (Fig $2 \mathrm{C}$ ). We

337 classified individuals as follows: i) early marine anadromous (Type 1) if age at migration from

338 fresh water was less than one; ii) as late freshwater anadromous (Type 2) if age- $0{ }^{87} \mathrm{Sr} /{ }^{86} \mathrm{Sr}$

339 represented time spent in fresh water and age at migration was greater than one; and iii) late

344 limited time in fresh water as larvae and frequently moving between freshwater, estuarine, and

\section{Results}

\section{Life history types}

Anadromous life history (Types 1-3) comprised a significant proportion of individuals 
Leppi et al. PLOS ONE 27 October 2021

357 (Fig 3A.). All anadromous individuals spent a portion of time (months to years) in fresh water

358 (Fig 4A-C) and had similar natal (Fig 3B) and juvenile rearing ${ }^{87} \mathrm{Sr} /{ }^{86} \mathrm{Sr}$ (Fig 3C). Following

359 initial migration to marine habitats, our results suggested that numerous anadromous individuals

360 shifted from annual marine habitat use (Fig 5A) to constant freshwater residency (Fig 5B). Semi-

361 anadromous (Type 4) individuals were the most common life history type and comprised $28 \%$ of

362 the population sampled (Fig 3A). The majority of these individuals had lower natal (Fig 3B) and

363 juvenile freshwater rearing (Fig 3C) ${ }^{87} \mathrm{Sr} /{ }^{86} \mathrm{Sr}$ reflective of estuarine habitats and ${ }^{87} \mathrm{Sr} /{ }^{86} \mathrm{Sr}$ near

364 the GMV that remained somewhat constant across time (Fig 4D). Nonanadromous individuals

365 (Type 5-6) were comparatively rare (13\%; Fig 3A), with freshwater estuarine nonanadromous

366 (Type 5) comprising 3\%, and freshwater resident (Type 6) comprising 10\% (Fig 3A). These

367 nonanadromous individuals had elevated freshwater natal region ${ }^{87} \mathrm{Sr} /{ }^{86} \mathrm{Sr}$ compared to the other

368 life history groups (Fig 3B) but had similar freshwater juvenile rearing ${ }^{87} \mathrm{Sr} /{ }^{86} \mathrm{Sr}$ (Fig $3 \mathrm{C}$ ).

369 Freshwater estuarine life history types mainly used habitat with ${ }^{87} \mathrm{Sr} /{ }^{86} \mathrm{Sr}$ within the range of

370 fresh waters, but on occasions these individuals used estuarine habitat (Fig 5C). Within the

371 freshwater resident life history type, some individuals appear to use freshwater habitats across a

372 spectrum of ${ }^{87} \mathrm{Sr} /{ }^{86} \mathrm{Sr}$ (Fig $4 \mathrm{~F}$ ), while others remain in habitat with relatively uniform values (Fig

$3735 \mathrm{D})$.

374 Fig 3. Otolith life history classification. Supervised classification of 61 Broad Whitefish

375 (Coregonus nasus) from the Colville River, AK, USA into six life history types based on

376 strategy (anadromous, semi-anadromous, nonanadromous), rearing habitat used (marine,

377 brackish, freshwater), and age at marine migration. Anadromous individuals (Types 1-3), semi-

378 anadromous (Type 4), and non-anadromous (Types 5-6) are individually colored by life history

379 type. Fitted Generalized Additive Model values of the first 850 raw ${ }^{87} \mathrm{Sr} /{ }^{86} \mathrm{Sr}$ (solid colored lines) 
Leppi et al. PLOS ONE 27 October 2021

and $95 \%$ confidence interval (grey shading) for each individual and life history type are shown in panel (A). The horizontal light blue line represents the global mean oceanic value (GMV $=$ $0.70918 \pm 0.00006)$. Panel (B) and (C) show boxplots of the freshwater natal region and the freshwater juvenile rearing region. Panel (D) shows boxplots for the age of first marine migration for each life history group. Each boxplot shows the median value $\left({ }^{87} \mathrm{Sr} /{ }^{86} \mathrm{Sr}\right.$ value or age) for each life history type (horizontal black line), IQR (box outline), the maximum value within 1.5 times the IQR (vertical black line), and outside values greater than 1.5 times the IQR (black dots).

Fig 4. Broad Whitefish life history examples. Selected otolith ${ }^{87} \mathrm{Sr} /{ }^{86} \mathrm{Sr}$ profiles for six Broad Whitefish (Coregonus nasus) from the Colville River, AK, USA, representative of each life history type. Fitted Generalize Additive Model values (solid-colored lines), 95\% confidence interval (grey shading), and raw ${ }^{87} \mathrm{Sr} /{ }^{86} \mathrm{Sr}$ for each life history type (black dots) from the otolith core to edge are shown. Life history types shown; early marine anadromous (A), late freshwater anadromous (B), late transitional anadromous (C), semi-anadromous (D), freshwater estuarine nonanadromous (E), freshwater resident (F). Thin dashed vertical black lines represent the end of each winter annular growth (annuli) for the first four years. The horizontal light blue line represents the global mean oceanic value $(\mathrm{GMV}=0.70918 \pm 0.00006)$.

Fig 5. Variation within anadromous and nonanadromous life history types. Variation within anadromous and nonanadromous life history types. Selected otolith ${ }^{87} \mathrm{Sr} /{ }^{86} \mathrm{Sr}$ profiles of four Broad Whitefish (Coregonus nasus) from the Colville River, AK, USA, displaying unique variation in anadromous and nonanadromous life history types. Fitted Generalized Additive Model values (solid-colored lines), 95\% confidence interval (grey shading), and raw ${ }^{87} \mathrm{Sr} /{ }^{86} \mathrm{Sr}$ for 
Leppi et al. PLOS ONE 27 October 2021

each life history type (black dots) from the otolith core to edge are shown. Freshwater late anadromous life history type displaying continued marine habitat use (A), freshwater late anadromous life history type displaying a switch to freshwater habitat later in life (B), freshwater estuarine nonanadromous life history type demonstrating delayed estuarine habitat use (C), and freshwater resident life history type demonstrating relatively stable ${ }^{87} \mathrm{Sr} /{ }^{86} \mathrm{Sr}$ across time (D). The horizontal light blue line represents the global mean oceanic value $(\mathrm{GMV}=0.70918 \pm 0.00006)$.

\section{Anadromous migration patterns}

Among the $59 \%$ classified as one of the three anadromous types, most individuals $(67 \%)$ initially migrated to sea between ages 0 and 2 (Table 2). All anadromous individuals spent months to years in fresh water, but comparisons of GAM values indicate that distinct patterns exist for anadromous types (Fig 3A). Age of marine migration varied based on life history (Table 2), but we found that $39 \%$ of individuals migrated to marine habitats at age- $0,25 \%$ migrated at age one, $3 \%$ migrated at age two, $6 \%$ at age three, no fish migrated at age 4 , and $3 \%$ migrated at age 5 (Fig 3D). Results also show large variation in the duration of marine habitat use (S1 Figure), with some individuals using marine habitats for only a few years, while others consistently use marine habitat until captured (Fig 5A; S1 Figure). Interestingly, our results also show that some adults later in life stop migrating to marine habitats and switch back to using freshwater habitats (Fig 5B; S1 Figure).

\section{Table 2. Age at migration for anadromous life history types of Broad Whitefish (Coregonus} nasus) caught in the Colville River, AK, USA. 
Leppi et al. PLOS ONE 27 October 2021

\begin{tabular}{|l|c|c|c|c|c|c|}
\hline \multirow{2}{*}{ Anadromous Life History Types } & \multicolumn{7}{|c|}{ Age at Marine Migration } \\
\cline { 2 - 7 } & Age 0 & Age 1 & Age 2 & Age 3 & Age 4 & Age 5 \\
\hline Early marine (Type 1, $\mathrm{n}=13)$ & $100 \%$ & $0 \%$ & $0 \%$ & $0 \%$ & $0 \%$ & $0 \%$ \\
\hline Late Freshwater (Type 2, $\mathrm{n}=14)$ & $0 \%$ & $71 \%$ & $7 \%$ & $14 \%$ & $0 \%$ & $7 \%$ \\
\hline Late Transistional (Type 3, $\mathrm{n}=9$ ) & $0 \%$ & $56 \%$ & $44 \%$ & $0 \%$ & $0 \%$ & $0 \%$ \\
\hline
\end{tabular}

426

427

\section{Freshwater natal and juvenile rearing region ${ }^{87} \mathrm{Sr} /{ }^{86} \mathrm{Sr}$}

A comparison of freshwater natal and juvenile rearing region ${ }^{87} \mathrm{Sr} /{ }^{86} \mathrm{Sr}$ across life history groups revealed several patterns. Anadromous life history types (early marine, late freshwater, late transitional) had similar values with mean natal region ${ }^{87} \mathrm{Sr} /{ }^{86} \mathrm{Sr}$ ranging from 0.71052 to 0.71083 (Table 3). Individuals with the semi-anadromous life history type had natal region ${ }^{87} \mathrm{Sr} /{ }^{86} \mathrm{Sr}$ centered at 0.70961 and were the lowest values observed (Table 3). Nonanadromous individuals (freshwater estuarine, freshwater resident) had mean natal region ${ }^{87} \mathrm{Sr} /{ }^{86} \mathrm{Sr}$ ranging from 0.71117 to 0.71122 and were the highest values observed (Table 3 ).

Freshwater juvenile rearing ${ }^{87} \mathrm{Sr} /{ }^{86} \mathrm{Sr}$ remained relatively constant for some life history types, while others varied. Freshwater juvenile rearing ${ }^{87} \mathrm{Sr} /{ }^{86} \mathrm{Sr}$ for anadromous life history types remained similar (range: $0.71048-0.71092$ ), but early marine anadromous life history type values decreased slightly (-0.00010), while late freshwater anadromous and late transitional anadromous ${ }^{87} \mathrm{Sr} /{ }^{86} \mathrm{Sr}$ increased $(+0.00009,+0.00004$; Table3). Semi-anadromous life history type ${ }^{87} \mathrm{Sr} /{ }^{86} \mathrm{Sr}$ remained at the lowest values, but freshwater juvenile rearing ${ }^{87} \mathrm{Sr} /{ }^{86} \mathrm{Sr}$ increased from natal values $(+0.00005$; Table 3$)$. Freshwater estuarine nonanadromous life history type ${ }^{87} \mathrm{Sr} /{ }^{86} \mathrm{Sr}$ decreased by -0.00018 to a mean value of 0.71087 , and freshwater resident life history type ${ }^{87} \mathrm{Sr} /{ }^{86} \mathrm{Sr}$ decreased slightly (-0.00009) to 0.71108 (Table 3). 
Leppi et al. PLOS ONE 27 October 2021

Table 3. Summary of GAM predicted ${ }^{87} \mathrm{Sr} /{ }^{86} \mathrm{Sr}$ for freshwater natal and freshwater

\begin{tabular}{|l|c|c|c|c|c|c|}
\hline & \multicolumn{7}{|c|}{${ }^{87} \mathrm{Sr} /{ }^{86} \mathrm{Sr}$} \\
\hline Freshwater natal region & Mean & Median & Min & Max & $\mathrm{SE}$ & $\mathrm{N}$ \\
\hline Early marine anadromous & 0.71058 & 0.71063 & 0.71025 & 0.71083 & 0.000023 & 12 \\
\hline Late freshwater anadromous & 0.71083 & 0.71088 & 0.71036 & 0.71097 & 0.000022 & 14 \\
\hline Late transitional anadromous & 0.71052 & 0.71051 & 0.71020 & 0.71084 & 0.000018 & 9 \\
\hline Semi-anadromous & 0.70961 & 0.70960 & 0.70958 & 0.70986 & 0.000011 & 6 \\
\hline Freshwater estuarine nonanadromous & 0.71106 & 0.71108 & 0.71055 & 0.71114 & 0.000026 & 2 \\
\hline Freshwater resident & 0.71117 & 0.71122 & 0.71062 & 0.71122 & 0.000020 & 6 \\
\hline Freshwater juvenile rearing region & \multicolumn{5}{|l|}{} \\
\hline Early marine anadromous & 0.71048 & 0.71050 & 0.70997 & 0.71091 & 0.000016 & 12 \\
\hline Late freshwater anadromous & 0.71092 & 0.71105 & 0.70981 & 0.71114 & 0.000020 & 14 \\
\hline Late transitional anadromous & 0.71056 & 0.71057 & 0.70992 & 0.71104 & 0.000009 & 8 \\
\hline Semi-anadromous & 0.70966 & 0.70962 & 0.70957 & 0.71008 & 0.000013 & 7 \\
\hline Freshwater estuarine nonanadromous & 0.71087 & 0.71090 & 0.71002 & 0.71113 & 0.000012 & 2 \\
\hline Freshwater resident & 0.71108 & 0.71115 & 0.70982 & 0.71120 & 0.000013 & 6 \\
\hline
\end{tabular}

447

Mean $=$ mean ${ }^{87} \mathrm{Sr} /{ }^{86} \mathrm{Sr}$, Median $=\operatorname{median}{ }^{87} \mathrm{Sr} /{ }^{86} \mathrm{Sr}, \mathrm{Min}=\operatorname{minimum}{ }^{87} \mathrm{Sr} /{ }^{86} \mathrm{Sr}, \mathrm{Max}=$ maximum ${ }^{87} \mathrm{Sr} /{ }^{86} \mathrm{Sr}, \mathrm{SE}=$ standard error of ${ }^{87} \mathrm{Sr} /{ }^{86} \mathrm{Sr}$, and $\mathrm{N}=$ number of unique otoliths within the classified life history type.

\section{Discussion}

Otolith microchemistry revealed a diversity of life histories in Broad Whitefish in the Colville River. Six different ${ }^{87} \mathrm{Sr} /{ }^{86} \mathrm{Sr}$ life history types were evident in the individuals examined, which included three anadromous, one semi-anadromous, and two nonanadromous life history types. Within each life history group, there also appears to be variation within freshwater habitats occupied during juvenile and adult stages and the time and duration spent in marine habitats. The majority of Broad Whitefish had anadromous life history types, but migration timing varied 
Leppi et al. PLOS ONE 27 October 2021

459

460

461

462

463

464

472

473

474

475

476

477 in the duration of freshwater and estuarine use prior to marine migration, which ranged from as

478 little as a month or so to several years. In other fish species, juvenile life history diversity

479 appears to be driven by differences in habitat quality and availability and the response of

greatly within life history types. These results support the pattern of increased life history diversity among species that live in environments subjected to frequent perturbations and extreme seasonal changes (e.g., shifting river channels, river ice growth up to $2 \mathrm{~m}$ thick), which can increase mortality risks [100]. study is generally consistent with other studies conducted on coregonins in Arctic and Boreal regions $[38,51,63,101]$. Research in the Mackenzie River watershed, in Yukon, Canada, showed multiple Broad Whitefish life histories [102], including anadromous, semi-anadromous, and nonanadromous (riverine and lacustrine) forms [38,53,103], with large variability in migration patterns and utilization of the watershed [104]. High variation in the timing of marine entry (years) by anadromous individuals was observed in the Mackenzie River, along with a high degree of variability in freshwater, estuarine, and marine habitat use [38]. In the Yukon River, Alaska, otolith Sr concentrations suggest a slow, gradual downstream movement by some individuals from freshwater to marine habitat over multiple years [51,88]. Our results generally corroborate this but also provide evidence for increased variation in occupied habitats within anadromous types than previously documented in Broad Whitefish. We found major differences

480 individuals to maximize fitness [105,106]. Chinook Salmon, for example, exhibit a continuum of 481 juvenile life history pathways, which are defined by the timing and transition among life stages 
Leppi et al. PLOS ONE 27 October 2021

482 and freshwater and marine habitats used for rearing [106]. These life history pathways are

483 influenced by local habitat and environmental conditions, such as water temperature, which

484 influences factors such as incubation duration, growth rate, and downstream migration [106]. In

485 many instances, Chinook Salmon that are exposed in warmer post-emergence water temperature

486 display higher growth rates, which generally results in earlier downstream migration [107].

487 Similar processes along with genetically-controlled traits, such as adult fish spawn timing and

488 adaptation to spawning environments, likely influence the diversity of Broad Whitefish life

489 histories documented here.

marine habitats throughout their lives, with minimal time spent in fresh water. This pattern

497 Salmon (Salmo salar) and Brown Trout (S. trutta) [109]. Semi-anadromous individuals were the

499 are significantly important for juvenile Broad Whitefish born in the Colville River.

501 Mackenzie rivers [51,38,102]. In the Yukon River drainage, nonanadromous individuals are less

502 common than anadromous individuals [51], with the exception of sites far inland (i.e., $2000 \mathrm{~km}$

503 from the coast) and in upstream tributaries like the Porcupine River. Similar patterns have been

504 observed in the Mackenzie River drainage, where nonanadromous individuals are uncommon 
Leppi et al. PLOS ONE 27 October 2021

505

506

507

508

509

510

511

512

513

514

515

516

517

518

519

520

521

522

523

524

525

526

527 braided channel networks to spawn, taking advantage of habitat that often contains high

and tend to be associated with lentic habitat $[38,103]$ or smaller tributaries (e.g., Arctic Red River) [104]. Our results show a similar pattern in the Colville River watershed but provide evidence for additional diversity within nonanadromous life history types. The observed habitat use of freshwater estuarine nonanadromous life history types suggests that certain individuals do not remain in one location and rather move between a variety of freshwater and estuarine habitats. Collectively, these findings suggest that migrating to sea is not energetically profitable for all Broad Whitefish, such as those requiring particularly long journeys, and that enough resources to reach sexual maturity can be acquired solely in fresh water.

\section{Age-0 movements}

The majority of Broad Whitefish appear to be transported from natal habitat to rearing habitat within the first year of life. Generally, otoliths indicated that individuals with life history types 1-2 and 5-6 left natal habitat and utilized freshwater rearing habitat with isotopically different values. Our results suggest that most larvae do not use natal habitat for rearing and instead are likely transported downstream to new habitat. In contrast to previous research, we found that numerous individuals $(n=13)$ entered marine habitat at age- 0 after spending little time in freshwater. To our knowledge, the rapid transition over days instead of weeks has not been documented but might be due to the proximity of spawning habitat to marine environments and the intensity of spring breakup streamflow on certain years. Across numerous freshwater fish species, there is evidence that spawning areas tend to be associated with shallow habitats [115] and provide refugia for eggs where instream conditions facilitate embryonic development and predation is minimal [116]. For example, salmon and trout commonly use small streams or 
Leppi et al. PLOS ONE 27 October 2021

hyporheic flow, consistent water temperatures, and gravel substrate [117,118,119]. Within heterogenous riverine environments, it is common for spawning habitats to differ from juvenile rearing habitats, which may also be distinct from adult habitats $[44,45]$. These patterns of habitat use has been documented for Broad Whitefish in the Yukon and Kuskokwim river drainages, where adults feed in lakes during the summer, spawn in upper reaches of the drainage during the fall, and larvae and juveniles rear in downstream delta or estuary habitat [49, 50, 52].

A subset of individuals exhibited minimal isotopic change between natal and juvenile rearing regions. The late transitional anadromous life history type (Type 3), for example, displayed minimal isotopic change, which could be caused by individuals being advected downstream to new rearing habitat that were isotopically similar prior to marine entry. The semianadromous type (Type 4) also had minimal isotopic change and, in this case, it is possible that they are not advected far or end up rearing in nearby freshwater habitat with isotopic values similar to natal areas (e.g., lakes, riverine habitat).

Identifying freshwater natal and juvenile rearing specific habitat is difficult due to the lack of empirical ${ }^{87} \mathrm{Sr} /{ }^{86} \mathrm{Sr}$ data, but several broad patterns emerged from comparing our results to coarse estimates of surface water ${ }^{87} \mathrm{Sr} /{ }^{86} \mathrm{Sr}\left(1 \mathrm{~km}^{2}\right.$ grids $)$ for surface waters across Alaska $[68,69]$. Broad Whitefish are known to spawn in wide channels with moderate braiding and gravel substrate $[49,50,88]$. Recent research in the Colville River estimates mainstem habitat to have the greatest intrinsic spawning potential [78], which is where we would expect natal habitat to be located, as opposed to smaller tributaries with similar ${ }^{87} \mathrm{Sr} /{ }^{86} \mathrm{Sr}$. Anadromous individuals that migrated to sea at age-0 (Type 1) had natal region ${ }^{87} \mathrm{Sr} /{ }^{86} \mathrm{Sr}$ that were higher than juvenile freshwater rearing region ${ }^{87} \mathrm{Sr} /{ }^{86} \mathrm{Sr}$, suggesting that individuals were born in the middle watershed where estimated ${ }^{87} \mathrm{Sr} /{ }^{86} \mathrm{Sr}$ is near 0.711 and then gradually decreases downstream. 
Leppi et al. PLOS ONE 27 October 2021

551 Late migrating anadromous individuals (Type 2-3) had juvenile region ${ }^{87} \mathrm{Sr} /{ }^{86} \mathrm{Sr}$ that were higher

552 than natal regions. This pattern could be explained by individuals hatching from eggs spawned

553 higher in the watershed, where the estimated ${ }^{87} \mathrm{Sr} /{ }^{86} \mathrm{Sr}$ range was near 0.710 , drifting downstream

554 to rear in habitats in the middle and lower watershed where estimated ${ }^{87} \mathrm{Sr} /{ }^{86} \mathrm{Sr}$ was generally

555 higher (ca. 0.711). Semi-anadromous individuals (Type 4) had natal and juvenile

556 region ${ }^{87} \mathrm{Sr} /{ }^{86} \mathrm{Sr}$ near the GMV (0.70918), which suggests they moved between areas in the lower

557 river, delta, and estuary. Nonanadromous individuals (Type 5-6) had higher natal region and

558 lower juvenile rearing values, suggesting they may have hatched in the middle watershed drifted

559 downstream to rear in the lower river or estuary, or in the case of the freshwater resident life

560 history type, remained in the spawning area.

561

562 Broad Whitefish conservation

Our research provides new insights into the complex patterns of lifetime habitat use by

Broad Whitefish. A portfolio of life history types suggests that Colville River Broad Whitefish

565 largely remain free from anthropogenic impacts that fragment or homogenize habitats. Within

566 life history types, individuals appear to use different habitats (freshwater, estuarine, and marine)

567 for varying durations (months to years) across each life stage, which suggests further complexity.

568 For example, an individual may hatch and spend less than one month or as much as five years in

569 freshwater before heading to sea. Once at sea, some individuals continue annual patterns of

570 marine migrations through life, while others migrate as mature adults to freshwater habitats they

571 have not previously occupied. There is certainly greater life history variation than the small

572 number of otolith ${ }^{87} \mathrm{Sr} /{ }^{86} \mathrm{Sr}$ profiles examined here would suggest. Similar diverse patterns of

573 habitat use have been documented for other fish species. Recent otolith microchemistry work 
Leppi et al. PLOS ONE 27 October 2021

574 with juvenile Chinook salmon, for example, demonstrated that individuals used a complex array

575 of habitat types to achieve maximum growth prior to ocean migration [120]. The diversity of life

576 histories found here suggests that Broad Whitefish populations experience frequent disturbance

577 or high environmental variability $[100,108,113]$.

Our research revealed the complexities of Broad Whitefish life histories and habitat use,

579 but further research is needed for the effective conservation of this important subsistence

580 resource. Understanding the variation in ${ }^{87} \mathrm{Sr} /{ }^{86} \mathrm{Sr}$ across the watershed is important for

581 identifying spawning habitats, which are essential to sustain Broad Whitefish populations and

582 may be disproportionally small [78] compared to other key habitats (e.g., feeding habitat). Once

583 identified, it will also be possible to understand the contribution of each spawning area to the

584 Nuiqsut subsistence fishery and potentially to other fisheries [62]. Broad Whitefish are a highly

585 migratory and long-lived fish, making it conceivable that fish caught outside the watershed (e.g.,

586 in the Utqiagvik, AK, fishery), may have originated from the Colville River. Lastly, another

587 challenge is understanding where fish go when they leave the Colville River watershed. Future

588 research that tracks the marine migration patterns and movement between watersheds across the

589 Arctic will likely provide key insights into a diversity of juvenile and adult foraging patterns and 590 migration routes.

591 Despite its historical and current importance as a subsistence species for Alaska's

592 Indigenous Beaufort Sea communities, little is known about the nature and distribution of their

593 essential habitats. Currently, infrastructure from oil and gas development is minimal within the

594 Colville watershed. However, as development continues to expand across the region, potentially

595 crossing and altering habitats in the Colville River and other watersheds utilized by Broad

596 Whitefish, it is important for land managers and conservation planners to understand the risks. 
Leppi et al. PLOS ONE 27 October 2021

597 Oil and gas development in the central Beaufort Sea region has caused cumulative impacts to

598 permafrost, such as flooding and pooling of water, and loss of vegetation due to heavy road dust

$599[121,122]$, which can cause flow modifications that affect habitat quality and connectivity. Arctic

600 oil and gas infrastructure (e.g., roads, pipelines) fragments and disrupts aquatic ecosystems along

601 linear paths [126], which can further introduce stressors to juvenile and adult fishes [25,123],

602 such as increased sedimentation [124-127], modifications of streamflow [128], obstructions to

603 passage [129-131], and reduced instream habitat quality [132], as well as pollution [133].

604 Climate change is also altering Arctic hydrologic regimes; variability in runoff is increasing [14],

605 and discharge from large Arctic rivers is increasing both annually $[15,16]$ and during winter [17],

606 and snow-dominated runoff regimes are shifting toward rainfall-dominated regimes [134].

607 Maintaining habitats to support complex life histories is critical for the long-term conservation of

608 Broad Whitefish and the loss of life history diversity will make the population more susceptible

609 to fluctuations in abundance and will increase the risk of extinction [135-137].

610

611

612

613

614

615

616

617

618

619 
Leppi et al. PLOS ONE 27 October 2021

620 Acknowledgments

621

622

623

624

625

626

627

628

629

630

631

632

633

634

635

636

637

638

639

640

641

642
We would like to thank the Alaska Cooperative Fish and Wildlife Research Unit (AKCFWRU) staff, Native Village of Nuiqsut (NVN) Tribal Council staff, U.S. Fish and Wildlife Service Fairbanks Fish and Aquatic Conservation Office staff, Bureau of Land Management (BLM) Arctic Office staff, and the Alaska Established Program to Stimulate Competitive Research for assistance with fieldwork and logistics. We also thank Jonah Nukapigak (NVN) for crucial field logistical support and for sharing his traditional knowledge, and Stuart Lehman, Mike Lunde (AKCFWRU), and Kristin Rine (AKCFWRU) for critical assistance in the field with Broad Whitefish capture. We also thank Lonnie Bryant (BLM) for assistance with summer activity permits and Richard Kemnitz (formerly BLM) for logistical help in Umiat, AK. We thank Josh Gage with Gage Cartographic for assistance with R code to help organize and analyze strontium otolith data. We thank Andrew C. Seitz (CFOS, UAF) and Jeffrey A. Falke (USGS AKCFWRU) for reviewing early manuscript drafts and providing constructive comments. Research was conducted under the Alaska Department of Fish and Game Fish Resource Permit \#SF2017-201 and under University of Alaska Fairbanks Institutional Animal Care and Use Committee Protocol \#901048. The findings and conclusions in this article are those of the authors and do not necessarily represent the views of the U.S. Fish and Wildlife Service. Any use of trade, firm, or product names is for descriptive purposes only and does not imply endorsement by the U.S. Government. 
Leppi et al. PLOS ONE 27 October 2021

\section{Author contributions}

644

645

646

647 feedback) from $\mathrm{MSW}^{4}$ and $\mathrm{MSW}^{7}$; manuscript preparation was led by $\mathrm{JCL}^{1,2}$, with support

648 (critical feedback, revisions, and additions to text) from all co-authors.

649

650

651

652

653

654

655

656

657

658

659

660

661

662

663

664

665 
Leppi et al. PLOS ONE 27 October 2021

\section{References}

1. Darwall W, Freyhof J. Lost fishes, who is counting? The extent of the threat to freshwater fish biodiversity. In: Closs GP, Olden JD, Krkosek M, editors. Conser Fresh Fish. Cambridge: Cambridge University Press; 2015. pp. 1-36. https://doi.org/10.1017/CBO9781139627085.002

2. Collen B, Whitton F, Dyer EE, Baillie JEM, Cumberlidge N, Darwall WRT, et al. Global patterns of freshwater species diversity, threat and endemism. Glob Ecol Biogeogr. 2014;23: 40-51. https://doi.org/10.1111/geb.12096

3. Almond REA, Grooten M, Petersen T. Living planet report 2020 - bending the curve of biodiversity loss. WWF, Gland, Switzerland; 2020. Available from: https://f.hubspotusercontent20.net/hubfs/4783129/LPR/PDFs/ENGLISH-FULL.pdf

4. Su G, Logez M, Xu J, Tao S, Villéger S, Brosse S. Human impacts on global freshwater fish biodiversity. Science. 2021;371: 835- 838. https://doi.org/10.1126/science.abd3369

5. Dawson MN. Species richness, habitable volume, and species densities in freshwater, the sea, and on land. Front Biogeogr. 2012;4. https://doi.org/10.21425/f5fbg12675

6. Palkovacs EP, Kinnison MT, Correa C, Dalton CM, Hendry AP. Fates beyond traits: ecological consequences of human-induced trait change. Evol Appl. 2012;5: 183-191. https://doi.org/10.1111/j.1752-4571.2011.00212.x

7. Reid AJ, Carlson AK, Creed IF, Eliason EJ, Gell PA, Johnson PTJ, et al. Emerging threats and persistent conservation challenges for freshwater biodiversity. Biol Rev. 2019;94: 849-873. https://doi.org/10.1111/brv.12480

8. Dudgeon D, Arthington AH, Gessner MO, Kawabata Z-I, Knowler DJ, Lévêque C, et al. Freshwater biodiversity: importance, threats, status and conservation challenges. Biol Rev. 2005/12/12. 2006;81: 163-182. https://doi.org/10.1017/S1464793105006950

9. Meredith M, Sommerkorn M, Cassotta S, Derksen C, Ekaykina A, Hollowed A. Polar regions. Intergovernmental Panel on Climate change (IPCC) special report on the ocean and cryosphere in a changing climate. 2019. pp. 203-320. https://doi.org/10.1016/S13667017(01)00066-6

10. Lento J, Goedkoop W, Culp J, Cristoffersen K, Larusson K, Fefilova E, et al. State of the Arctic freshwater biodiversity. Conservation of Arctic Flora and Fauna International Secretariat, Akureyri, Iceland; 2019. Available from: http://www.arcticbiodiversity.is/freshwater 
Leppi et al. PLOS ONE 27 October 2021

11. Larsen JN, Anisimov OA, Constable A, Hollowed AB, Maynard N, Prestrud P, TD Prowse, MRStone. Polar regions. In: Field CB, Dokken DJ, Mastrandrea MD, Mach KJ, Bilir TE, Mastrandrea MD, Mach KJ, Bilir TE, Chatterjee M, Ebi KL, Estrade YO, Genova RC, Girma B, Kissel ES, Levy AN, MacCracken S, Mastrandrea PR and White LL, editors. Climate change 2014: impacts, adaptation, and vulnerability part b: regional aspects contribution of working group II to the fifth assessment report of the Intergovernmental Panel on Climate Change. Cambridge: Cambridge University Press; 2014. pp. 1567-1612. Available from: https://www.ipcc.ch/site/assets/uploads/2018/02/WGIIAR5-Chap28_FINAL.pdf

12. Overland J, Dunlea E, Box JE, Corell R, Forsius M, Kattsov V, et al. The urgency of Arctic change. Polar Sci. 2019;21: 6-13. https://doi.org/10.1016/j.polar.2018.11.008

13. Heino J, Virkkala R, Toivonen H. Climate change and freshwater biodiversity: detected patterns, future trends and adaptations in northern regions. Biol Rev. 2009;84: 39-54. https://doi.org/10.1111/j.1469-185X.2008.00060.x

14. Stuefer SL, Arp CD, Kane DL, Liljedahl AK. Recent extreme runoff observations from coastal Arctic watersheds in Alaska. Water Resour Res. 2017;53: 9145-9163. https://doi.org/10.1002/2017WR020567

15. Peterson BJ, Holmes RM, McClelland JW, Vörösmarty CJ, Lammers RB, Shiklomanov AI, et al. Increasing river discharge to the Arctic Ocean. Science. 2002;298: 2171-2173. https://doi.org/10.1126/science.1077445

16. Shiklomanov AI, Lammers RB. Record Russian River discharge in 2007 and the limits of analysis. Environ Res Lett. 2009;4. https://doi.org/10.1088/1748-9326/4/4/045015

17. Smith LC, Pavelsky TM, MacDonald GM, Shiklomanov AI, Lammers RB. Rising minimum daily flows in northern Eurasian rivers: a growing influence of groundwater in the high-latitude hydrologic cycle. J Geophys Res Biogeosciences. 2007;112. https://doi.org/10.1029/2006JG000327

18. Van Vliet MTH, Franssen WHP, Yearsley JR, Ludwig F, Haddeland I, Lettenmaier DP, et al. Global river discharge and water temperature under climate change. Glob Environ Chang. 2013;23: 450-464. https://doi.org/10.1016/j.gloenvcha.2012.11.002

19. Arp CD, Jones BM, Grosse G, Bondurant AC, Romanovsky VE, Hinkel KM, et al. Threshold sensitivity of shallow Arctic lakes and sub-lake permafrost to changing winter climate. Geophys Res Lett. 2016;43: 6358-6365. https://doi.org/10.1002/2016GL068506

20. Smol JP, Douglas MS V. Crossing the final ecological threshold in high Arctic ponds. Proc Natl Acad Sci. 2007;104: 12395-12397. https://doi.org/10.1073/pnas.0702777104

21. Hayden B, Myllykangas J-P, Rolls RJ, Kahilainen KK. Climate and productivity shape fish and invertebrate community structure in subarctic lakes. Freshw Biol. 2017;62: 9901003. https://doi.org/10.1111/fwb.12919 
Leppi et al. PLOS ONE 27 October 2021

22. Hayden B, Harrod C, Thomas SM, Eloranta AP, Myllykangas J-P, Siwertsson A, et al. From clear lakes to murky waters - tracing the functional response of high-latitude lake communities to concurrent 'greening' and 'browning.' Ecol Lett. 2019;22: 807-816. https://doi.org/10.1111/ele.13238

23. Huser BJ, Futter MN, Bogan D, Brittain JE, Culp JM, Goedkoop W, et al. Spatial and temporal variation in Arctic freshwater chemistry - reflecting climate-induced landscape alterations and a changing template for biodiversity. Freshw Biol. 2020;n/a. https://doi.org/10.1111/fwb.13645

24. Campana SE, Casselman JM, Jones CM, Black G, Barker O, Evans M, et al. Arctic freshwater fish productivity and colonization increase with climate warming. Nat Clim Chang. 2020;10: 428-433. https://doi.org/10.1038/s41558-020-0744-x

25. Cott PA, Schein A, Hanna BW, Johnston TA, MacDonald DD, Gunn JM. Implications of linear developments on northern fishes. Environ Rev. 2015;23: 177-190. https://doi.org/10.1139/er-2014-0075

26. Dudgeon D. Multiple threats imperil freshwater biodiversity in the Anthropocene. Curr Biol. 2019;29: R960-R967. https://doi.org/10.1016/j.cub.2019.08.002

27. Goldsmit J, Archambault P, Chust G, Villarino E, Liu G, Lukovich J V, et al. Projecting present and future habitat suitability of ship-mediated aquatic invasive species in the Canadian Arctic. Biol Invasions. 2018;20: 501-517. https://doi.org/10.1007/s10530-017$1553-7$

28. Taranu ZE, Gregory-Eaves I, Leavitt PR, Bunting L, Buchaca T, Catalan J, et al. Acceleration of cyanobacterial dominance in north temperate-subarctic lakes during the Anthropocene. Ecol Lett. 2015;18: 375-384. https://doi.org/10.1111/ele.12420

29. Moore JW, Yeakel JD, Peard D, Lough J, Beere M. Life history diversity and its importance to population stability and persistence of a migratory fish: steelhead in two large North American watersheds. J Anim Ecol. 2014;83: 1035-1046. https://doi.org/10.1111/1365-2656.12212

30. Hughes JB, Daily GC, Ehrlich PR. Population diversity: its extent and extinction. Science. 1997;278: 689-692. https://doi.org/10.1126/science.278.5338.689

31. Greene CM, Hall JE, Guilbault KR, Quinn TP. Improved viability of populations with diverse life history portfolios. Biol Lett. 2010;6: 382-386.

https://doi.org/10.1098/rsbl.2009.0780

32. Heim KC, McMahon TE, Calle L, Wipfli MS, Falke JA. A general model of temporary aquatic habitat use: water phenology as a life history filter. Fish Fish. 2019;0. https://doi.org/10.1111/faf.12386 
Leppi et al. PLOS ONE 27 October 2021

33. Haynes TB, Rosenberger AE, Lindberg MS, Whitman M, Schmutz JA. Patterns of lake occupancy by fish indicate different adaptations to life in a harsh Arctic environment. Freshw Biol. 2014;59: 1884-1896. https://doi.org/10.1111/fwb.12391

34. Stearns SC. Life history evolution: successes, limitations, and prospects. Naturwissenschaften. 2000;87: 476-486. https://doi.org/10.1007/s001140050763

35. Hutchings JA, Morris DW. The influence of phylogeny, size and behaviour on patterns of covariation in salmonid life histories. Oikos. 1985;45: 118-124.

https://doi.org/10.2307/3565229

36. Brown RJ, Courtney MB, Seitz AC. New insights into the biology of anadromous Dolly Varden in the Canning River, Arctic National Wildlife Refuge, Alaska. Trans Am Fish Soc. 2019;148: 73-87. https://doi.org/10.1002/tafs.10122

37. Brown RJ, Loewen MB, Tanner TL. Overwintering locations, migrations, and fidelity of radio-tagged Dolly Varden in the Hulahula River, Arctic National Wildlife Refuge, 200709. Arctic. 2014;67: 149-158. https://doi.org/10.14430/arctic4379

38. Harris LN, Loewen TN, Reist JD, Halden NM, Babaluk JA, Tallman RF. Migratory variation in Mackenzie River system broad whitefish: insights from otolith strontium distributions. Trans Am Fish Soc. 2012;141: 1574-1585.

https://doi.org/10.1080/00028487.2012.713885

39. Harris LN, Swanson HK, Gilbert MJH, Malley BK, Fisk AT, Moore J-S. Anadromy and marine habitat use of Lake trout (Salvelinus namaycush) from the central Canadian Arctic. J Fish Biol. 2020;96: 1489-1494. https://doi.org/10.1111/jfb.14305

40. Irvine J, Macdonald R, Brown R, Godbout L, Reist J, Carmack E. Salmon in the Arctic and how they avoid lethal low temperatures. North Pacific Anadromous Fish Comm Bull. 2009;5: 39-50. Available from: https://npafc.org/bulletin-5/

41. Ranta E, Tesar D, Kaitala V. Environmental variability and semelparity vs. iteroparity as life histories. J Theor Biol. 2002;217: 391-396. https://doi.org/10.1006/jtbi.2002.3029

42. Orzack SH, Tuljapurkar S. Population dynamics in variable environments. VII. The demography and evolution of iteroparity. Am Nat. 1989;133: 901-923. https://doi.org/10.1086/284959

43. Leggett WC, Carscadden JE. Latitudinal variation in reproductive characteristics of American Shad (Alosa sapidissima): evidence for population specific life history strategies in fish. J Fish Res Board Canada. 1978;35: 1469-1478. https://doi.org/10.1139/f78-230 
Leppi et al. PLOS ONE 27 October 2021

44. Schlosser IJ. Stream fish ecology: a landscape perspective. Bioscience. 1991;41: 704-712. https://doi.org/10.2307/1311765

45. Schlosser IJ. Critical landscape attributes that influence fish population dynamics in headwater streams. Hydrobiologia. 1995;303: 71-81. https://doi.org/10.1007/BF00034045

46. Hilborn R, Quinn TP, Schindler DE, Rogers DE. Biocomplexity and fisheries sustainability. Proc Natl Acad Sci. 2003;100: 6564-6568. https://doi.org/10.1073/pnas.1037274100

47. Schindler DE, Hilborn R, Chasco B, Boatright CP, Quinn TP, Rogers LA, et al. Population diversity and the portfolio effect in an exploited species. Nature. 2010;465: 609-612. https://doi.org/10.1038/nature09060

48. Schindler DE, Armstrong JB, Reed TE. The portfolio concept in ecology and evolution. Front Ecol Environ. 2015;13: 257-263. https://doi.org/10.1890/140275

49. Brown RJ, Brown C, Braem NM, Carter III WK, Legere N, Slayton L. Whitefish biology, distribution, and fisheries in the Yukon and Kuskokwim River drainages in Alaska: a synthesis of available information. US Fish Wildl Serv Alaska Fish Data Ser 2012-4. 2012. Available from: https:/www.fws.gov/alaska/sites/default/files/pdfs/fisheries/dataseries/d_2012_4.pdf

50. Harper KC, Harris F, Miller SJ, Thalhauser JM, Ayers SD. Life history traits of adult broad whitefish and humpback whitefish. J Fish Wildl Manag. 2012;3: 56-75. https://doi.org/10.3996/022011-JFWM-011

51. Brown RJ, Bickford N, Severin K. Otolith trace element chemistry as an indicator of anadromy in Yukon River drainage coregonine fishes. Trans Am Fish Soc. 2007;136: 678-690. https://doi.org/10.1577/T06-040.1

52. Brown RJ. Distribution and demographics of whitefish species in the upper Koyukuk River drainage, Alaska, with emphasis on seasonal migrations and important habitats of broad whitefish and humpback whitefish. US Fish Wildl Serv Alaska Fish Tech Rep No 104. 2009. Available from: https://www.arlis.org/docs/vol1/B/495849598.pdf

53. Tallman R, Abrahams M, Chudobiak D. Migration and life history alternatives in a high latitude species, the broad whitefish, Coregonus nasus Pallas. Ecol Freshw Fish. 2002;11: 101-111. https://doi.org/10.1034/j.1600-0633.2002.00001.x

54. Reshetnikov YS, Bogdanov VD. Features of reproduction of whitefishes. J Ichthyol. 2011;51: 432-456. https://doi.org/10.1134/S0032945211030118

55. Martin DJ, Whitmus CK, Hachmeister LE, Volk EC, Schroder SL. Distribution and seasonal abundance of juvenile salmon and other fishes in the Yukon Delta. US Dep Commer Natl Oceanogr Atmos Adm Outer Cont Shelf Environ Assess Program, Final Reports Princ Investig. 1987. Available from: https://espis.boem.gov/final\%20reports/86.pdf 
Leppi et al. PLOS ONE 27 October 2021

56. Bond WA. A study of the fishery resources of Tuktoyaktuk Harbour, southern Beaufort Sea Coast, with special reference to life histories of anadromous coregonids. Department of Fisheries and Oceans, Can Tech Rep Fish and Aqut Sci, No. 119, Winnipeg. 1982. Available from: https://publications.gc.ca/site/eng/454445/publication.html

57. Næsje TF, Jonsson B, Sandlund OT. Drift of cisco and whitefish larvae in a Norwegian River. Trans Am Fish Soc. 1986;1: 89-93. https://doi.org/10.1577/15488659(1986)115<89

58. Bacon JJ, Hepa TR, Brower HKJ, Pedersen M, Olemaun TP, George JC, et al. Estimates of subsistence harvest for villages on the North Slope of Alaska, 1994-2003. N Slpe Borgh Depart, Barrow, 2011. Available from: http://www.northslope.org/assets/images/uploads/MASTER\%20SHDP\%209403\%20REPORT\%20FINAL\%20and\%20\%20Errata\%20info\%20(Sept\%202012).pdf

59. Brown CL, Braem NM, Kostick ML, Trainor A, Slayton LJ, Runfola DM, et al. Harvests and uses of wild resources in 4 interior Alaska communities and 3 Arctic Alaska communities, 2014. Alaska Dept Fish Game Div Subsis, Tech Pap No. 426, Fairbanks 2016. Available from: https://www.arlis.org/docs/vol1/M/972886420.pdf

60. Alaska Department of Fish and Game Community Subsistence Information System (CSIS). Data for Barrow and Nuiqsut; 2014 [cited 2021 May 19]. Database: CSIS [internet]. Available from: http://www.adfg.alaska.gov/sb/csis/

61. Kennedy BP, Klaue A, Blum JD, Folt CL, Nislow KH. Reconstructing the lives of fish using Sr isotopes in otoliths. Can J Fish Aquat Sci. 2002;59: 925-929. https://doi.org/10.1139/f02-070

62. Brennan SR, Zimmerman CE, Fernandez DP, Cerling TE, McPhee M V, Wooller MJ. Strontium isotopes delineate fine-scale natal origins and migration histories of Pacific salmon. Sci Adv. 2015;1: e1400124. https://doi.org/10.1126/sciadv.1400124

63. Padilla AJ, Brown RJ, Wooller MJ. Determining the movements and distribution of anadromous Bering ciscoes by use of otolith strontium isotopes. Trans Am Fish Soc. 2016;145: 1374-1385. https://doi.org/10.1080/00028487.2016.1225599

64. Hegg JC, Giarrizzo T, Kennedy BP. Diverse early life history strategies in migratory Amazonian catfish: implications for conservation and management. PLOS ONE. 2015;10: e0129697. https://doi.org/10.1371/journal.pone.0129697

65. Hobbs JA, Lewis LS, Willmes M, Denney C, Bush E. Complex life histories discovered in a critically endangered fish. Sci Rep. 2019;9: 16772. https://doi.org/10.1038/s41598-019$52273-8$

66. Austin CS, Bond MH, Smith JM, Lowery ED, Quinn TP. Otolith microchemistry reveals partial migration and life history variation in a facultatively anadromous, iteroparous salmonid, bull trout (Salvelinus confluentus). Environ Biol Fishes. 2019;102: 95-104. https://doi.org/10.1007/s10641-019-0848-1 
Leppi et al. PLOS ONE 27 October 2021

67. Campana SE. Chemistry and composition of fish otoliths: pathways, mechanisms and applications. Mar Ecol Prog Ser. 1999;188: 263-297. https://doi.org/10.3354/meps188263

68. Brennan SR, Fernandez DP, Mackey G, Cerling TE, Bataille CP, Bowen GJ, et al. Strontium isotope variation and carbonate versus silicate weathering in rivers from across Alaska: implications for provenance studies. Chem Geol. 2014;389: 167-181. https://doi.org/10.1016/j.chemgeo.2014.08.018

69. Bataille CP, Brennan SR, Hartmann J, Moosdorf N, Wooller MJ, Bowen GJ. A geostatistical framework for predicting variations in strontium concentrations and isotope ratios in Alaskan rivers. Chem Geol. 2014;389: 1-15. https://doi.org/10.1016/j.chemgeo.2014.08.030

70. Bataille CP, Bowen GJ. Mapping ${ }^{87} \mathrm{Sr} /{ }^{86} \mathrm{Sr}$ variations in bedrock and water for large scale provenance studies. Chem Geol. 2012;304-305: 39-52.

https://doi.org/10.1016/j.chemgeo.2012.01.028

71. Capo RC, Stewart BW, Chadwick OA. Strontium isotopes as tracers of ecosystem processes: theory and methods. Geoderma. 1998;82: 197-225. https://doi.org/10.1016/S0016-7061(97)00102-X

72. Blum JD, Erel Y, Brown K. ${ }^{87} \mathrm{Sr} /{ }^{86} \mathrm{Sr}$ ratios of Sierra Nevada stream waters: implications for relative mineral weathering rates. Geochim Cosmochim Acta. 1993;57: 5019-5025. https://doi.org/10.1016/S0016-7037(05)80014-6

73. Horton TW, Chamberlain CP, Fantle M, Blum JD. Chemical weathering and lithologic controls of water chemistry in a high-elevation river system: Clark's Fork of the Yellowstone River, Wyoming and Montana. Water Resour Res. 1999;35: 1643-1655. https://doi.org/10.1029/1998WR900103

74. Hüssy K, Limburg KE, de Pontual H, Thomas ORB, Cook PK, Heimbrand Y, et al. Trace elem https://doi.org/10.1080/23308249.2020.1760204

75. Barnett-Johnson R, Pearson TE, Ramos FC, Grimes CB, MacFarlane BR. Tracking natal origins of salmon using isotopes, otoliths, and landscape geology. Limnol Oceanogr. 2008;53: 1633-1642. https://doi.org/10.1111/j.1095-8649.2009.02394.x 10.4319/lo.2008.53.4.1633

76. Loewen TN, Gillis D, Tallman RF. Ecological niche specialization inferred from morphological variation and otolith strontium of Arctic charr Salvelinus alpinus L. found within open lake systems of southern Baffin Island, Nunavut, Canada. J Fish Biol. 2009;75: 1473-1495. https://doi.org/10.1111/j.1095-8649.2009.02394.x

77. Alt KT, Kogl DR. Notes on the whitefish of the Colville River, Alaska. J Fish Res Board Canada. 1973;30: 554-556. https://doi.org/10.1139/f73-094 
Leppi et al. PLOS ONE 27 October 2021

78. Leppi JC. Broad Whitefish (Coregonus nasus) ecology and habitat use in Arctic Alaska: spawning habitat suitability, isotopic niches, life-history variations, and climate change risks to subsistence fisheries. Ph.D. Dissertation, University of Alaska Fairbanks. 2021. Available from: https://www.proquest.com/openview/0ca0ff9a682772615e3c282ac70132a1/1?pqorigsite $=$ gscholar $\&$ cbl $=18750 \&$ diss $=y$

79. Craig PC. Fish use of coastal waters of the Alaskan Beaufort Sea: a review. Trans Am Fish Soc. 1984;113: 265-282. https://doi.org/10.1577/15488659(1984)113<265:FUOCWO >2.0.CO;2

80. Jorgenson MT, Brown J. Classification of the Alaskan Beaufort Sea Coast and estimation of carbon and sediment inputs from coastal erosion. Geo-Marine Lett. 2005;25: 69-80. https://doi.org/10.1007/s00367-004-0188-8

81. Jorgenson MT, Shur Y. Evolution of lakes and basins in northern Alaska and discussion of the thaw lake cycle. J Geophys Res Earth Surf. 2007;112. https://doi.org/10.1029/2006JF000531

82. Arp CD, Whitman MS, Jones BM, Kemnitz R, Grosse G, Urban FE. Drainage network structure and hydrologic behavior of three lake-rich watersheds on the Arctic Coastal Plain, Alaska. Arctic, Antarct, Alp Res. 2012;44: 385-398. https://doi.org/10.1657/19384246-44.4.385

83. Grosse G, Jones B, Arp C. Thermokarst lakes, drainage, and drained basins. In: Shroder J, editor in chief, Giardino R, Harbor J, editor. Treatise on Geomorphology. San Diego: Academic Press; 2013. pp. 325-353. https://doi.org/10.1016/B978-0-12-374739-6.002165

84. Montgomery DR, Buffington JM. Channel-reach morphology in mountain drainage basins. GSA Bull. 1997;109: 596-611. https://doi.org/10.1130/00167606(1997)109<0596:CRMIMD>2.3.CO;2

85. Knighton D. Fluvial forms and processes: a new perspective. Oxford University Press; 1998.

86. Brennan SR, Torgersen CE, Hollenbeck JP, Fernandez DP, Jensen CK, Schindler DE. Dendritic network models: improving isoscapes and quantifying influence of landscape and in-stream processes on strontium isotopes in rivers. Geophys Res Lett. 2016;43: 5043-5051. https://doi.org/10.1002/2016GL068904

87. Shulski M and Wendler G. The climate of Alaska. Fairbanks: University of Alaska Press; 2007.

88. Carter WK. Life history and spawning movements of broad whitefish in the middle Yukon River. M.S. Thesis, University of Alaska Fairbanks. 2010. Available from: https://citeseerx.ist.psu.edu/viewdoc/download?doi=10.1.1.383.4750\&rep=rep1\&type=pdf 
Leppi et al. PLOS ONE 27 October 2021

89. Secor D, Dean J, Laban E. Otolith removal and preparation for microstructural examination. In: Stevenson D, Campana S, editors. Otolith Microstructure Examination and Analysis. Can Spec Publ Fish Aquat Sci.1992;117, pp. 13-17. https://doi.org/10.13140/RG.2.2.22258.61127

90. Stevenson DK, Campana SE. Otolith Microstructure Examination and Analysis. Can Spec Publ Fish Aquat Sci. 1992;117. Available from: https://publications.gc.ca/site/eng/9.811462/publication.html

91. Chilton DE, Beamish RJ. Age determination methods for fishes studied by the groundfish program at the Pacific Biological Station. Can Spec Publ Fish Aquat Sci 60. 1982; 102. Available from: https://publications.gc.ca/site/eng/9.816313/publication.html

92. Prohaska T, Irrgeher J, Zitek A. Simultaneous multi-element and isotope ratio imaging of fish otoliths by laser ablation split stream ICP-MS/MC ICP-MS. J Anal At Spectrom. 2016;31: 1612-1621. https://doi.org/10.1039/C6JA00087H

93. Bullen TD, Kendall C. Chapter 18 - tracing of weathering reactions and water flowpaths: a multi-isotope approach. In: Kendll C, McDonnell J, editors. Isotope Tracers in Catchment Hydrology. Amsterdam: Elsevier; 1998. pp. 611-646. https://doi.org/10.1016/B978-0444-81546-0.50025-2

94. Secor DH, Rooker JR. Is otolith strontium a useful scalar of life cycles in estuarine fishes? Fish Res. 2000;46: 359-371. https://doi.org/10.1016/S0165-7836(00)00159-4

95. Irrgeher J, Galler P, Prohaska T. ${ }^{87} \mathrm{Sr} /{ }^{86} \mathrm{Sr}$ isotope ratio measurements by laser ablation multicollector inductively coupled plasma mass spectrometry: reconsidering matrix interferences in bioapatites and biogenic carbonates. Spectrochim Acta Part B At Spectrosc. 2016;125: 31-42. https://doi.org/10.1016/j.sab.2016.09.008

96. Wood SN. Stable and efficient multiple smoothing parameter estimation for generalized additive models. J Am Stat Assoc. 2004;99: 673-686. https://doi.org/10.1198/016214504000000980

97. Brennan SR, Fernandez DP, Zimmerman CE, Cerling TE, Brown RJ, Wooller MJ. Strontium isotopes in otoliths of a non-migratory fish (slimy sculpin): implications for provenance studies. Geochim Cosmochim Acta. 2015;149: 32-45. https://doi.org/10.1016/j.gca.2014.10.032

98. Wood SN. Fast stable restricted maximum likelihood and marginal likelihood estimation of semiparametric generalized linear models. J R Stat Soc Ser B (Statistical Methodol). 2011;73: 3-36. https://doi.org/10.1111/j.1467-9868.2010.00749.x

99. Barnett-Johnson R, Grimes C, Royer C, Donohoe C. Identifying the contribution of wild and hatchery Chinook salmon (Oncorhynchus tshawytscha) to the ocean fishery using otolith microstructure as natural tags. Can J Fish Aquat Sci. 2007;64: 1683-1692. https://doi.org/10.1139/f07-129 
Leppi et al. PLOS ONE 27 October 2021

100. Lytle DA. Disturbance regimes and life-history evolution. Am Nat. 2001;157: 525-536. https://doi.org/10.1086/319930

101. Stuby L. Contributions to the life history of Kuskokwim River inconnu. Trans Am Fish Soc. 2018;147: 879-890. https://doi.org/10.1002/tafs.10069

102. Chang-Kue KTJ, Jessop EF. The life history and habitat usage of broad whitefish in the lower Mackenzie River basin. Canadian Technical Report of Fisheries and Aquatic Sciences 2193: the proceedings of the broad whitefish workshop; the biology, traditional knowledge and scientific management of broad whitefish (Coregonus nasus (Pallus)) in the lower Mackenzie River. 1997. pp. 117-146. Available from: https://publications.gc.ca/collections/collection_2014/mpo-dfo/Fs97-6-2193-eng.pdf

103. Millar NP, Harris LN, Howland KL. Seasonal migrations of broad whitefish (Coregonus nasus (Pallas)) in an Arctic lake. Adv Limnol. 2013;64: 91-107. https://doi.org/10.1127/1612-166X/2013/0064-0010

104. Hodgson EE, Hovel RA, Ward EJ, Lord S, Moore JW. Migratory diversity in an Arctic fish supporting subsistence harvest. Biol Conserv. 2020;248: 108685. https://doi.org/10.1016/j.biocon.2020.108685

105. Satterthwaite WH, Hayes SA, Merz JE, Sogard SM, Frechette DM, Mangel M. Statedependent migration timing and use of multiple habitat types in anadromous salmonids. Trans Am Fish Soc. 2012;141: 781-794. https://doi.org/10.1080/00028487.2012.675912

106. Bourret SL, Caudill CC, Keefer ML. Diversity of juvenile Chinook salmon life history pathways. Rev Fish Biol Fish. 2016;26: 375-403. https://doi.org/10.1007/s11160-0169432-3

107. Beckman BR, Larsen DA, Lee-Pawlak B, Dickhoff WW. Relation of fish size and growth rate to migration of spring Chinook salmon smolts. N Am J Fish Manag. 1998;18:37-41. https://doi.org/10.1577/1548-8675(1998)018<0537:ROFSAG >2.0.CO;2

108. Southwood TRE. Habitat, the templet for ecological strategies? J Anim Ecol. 1977;46: 337-365. https://doi.org/10.2307/3817

109. Jonsson B, Jonsson N. Habitats as template for life histories. Ecology of Atlantic Salmon and Brown Trout: habitat as a template for life histories. Dordrecht: Springer Netherlands; 2011. pp. 1-21. https://doi.org/10.1007/978-94-007-1189-1_1

110. Tockner K, Malard F, Ward J V. An extension of the flood pulse concept. Hydrol Process. 2000;14: 2861-2883. https://doi.org/10.1002/1099-1085(200011/12)14:16/17<2861::AIDHYP124>3.0.CO;2-F 
Leppi et al. PLOS ONE 27 October 2021

112. Resh VH, Brown A V, Covich AP, Gurtz ME, Li HW, Minshall GW, et al. The role of disturbance in stream ecology. J North Am Benthol Soc. 1988;7: 433-455. https://doi.org/10.2307/1467300

113. Mims MC, Olden JD. Life history theory predicts fish assemblage response to hydrologic regimes. Ecology. 2012;93: 35-45. https://doi.org/10.1890/11-0370.1

114. Mims M, Olden J. Fish assemblages respond to altered flow regimes via ecological filtering of life history strategies. Freshw Biol. 2013;58: 50-62. https://doi.org/10.1111/fwb.12037

115. Lobb III MD, Orth DJ. Habitat use by an assemblage of fish in a large warmwater stream. Trans Am Fish Soc. 1991;120: 65-78. https://doi.org/10.1577/15488659(1991) $120<0065:$ HUBAAO $>2.3 . \mathrm{CO} ; 2$

116. Schlosser IJ. The role of predation in age- and size-related habitat use by stream fishes. Ecology. 1987;68: 651-659. https://doi.org/10.2307/1938470

117. Baxter CV and Hauer FR. Geomorphology, hyporheic exchange, and selection of spawning habitat by bull trout (Salvelinus confluentus). Can J Fish Aquat Sci. 2000; 57:1470-1481. https://doi.org/10.1139/f00-056

118. Bean JR, Wilcox AC, Woessner WW, Muhlfeld CC. Multiscale hydrogeomorphic influences on bull trout (Salvelinus confluentus) spawning habitat. Can J Fish Aquat Sci. 2014; 72:514-526. https://doi.org/10.1139/cjfas-2013-0534

119. BjornnT, Reiser D. Habitat requirements of salmonids in streams. In W. Meehan, editor. Influences of forest and rangeland management on salmonid fishes and their habitats. Amer Fish Soc Spec Pub.1991, pp 83-138.

120. Brennan SR, Cline TJ, Schindler DE. Quantifying habitat use of migratory fish across riverscapes using space-time isotope models. Methods Ecol Evol. 2019;10: 1036-1047. https://doi.org/10.1111/2041-210X.13191

121. Raynolds MK, Walker DA, Ambrosius KJ, Brown J, Everett KR, Kanevskiy M, et al. Cumulative geoecological effects of 62 years of infrastructure and climate change in icerich permafrost landscapes, Prudhoe Bay Oilfield, Alaska. Glob Chang Biol. 2014;20: 1211-1224. https://doi.org/10.1111/gcb.12500

122. Walker DA, Webber PJ, Binnian EF, Evertt KR, Lederer ND, Nordstrand EA, et al. Cumulative impacts of oil fields on northern Alaskan landscapes. Science. 1987;238: 757 LP - 761. https://doi.org/10.1126/science.238.4828.757

123. Trombulak SC, Frissell CA. Review of ecological effects of roads on terrestrial and aquatic communities. Conserv Biol. 2000;14: 18-30. https://doi.org/10.1046/j.15231739.2000.99084.x 
Leppi et al. PLOS ONE 27 October 2021

124. Burkhead NM, Jelks HL. Effects of suspended sediment on the reproductive success of the tricolor shiner, a crevice-spawning minnow. Trans Am Fish Soc. 2001;130: 959-968. https://doi.org/10.1577/1548-8659(2001)130<0959:EOSSOT>2.0.CO;2

125. Kjelland ME, Woodley CM, Swannack TM, Smith DL. A review of the potential effects of suspended sediment on fishes: potential dredging-related physiological, behavioral, and transgenerational implications. Environ Syst Decis. 2015;35: 334-350. https://doi.org/0.1007/s10669-015-9557-2

126. Sutherland AB. Effects of increased suspended sediment on the reproductive success of an upland crevice-spawning minnow. Trans Am Fish Soc. 2007;136: 416-422. https://doi.org/10.1577/T06-046.1

127. Chapman DW. Critical review of variables used to define effects of fines in redds of large salmonids. Trans Am Fish Soc. 1988;117: 1-21. https://doi.org/10.1577/15488659(1988)117<0001:CROVUT>2.3.CO;2

128. Flowers HJ, Pine III WE, Dutterer AC, Johnson KG, Ziewitz JW, Allen MS, et al. Spawning site selection and potential implications of modified flow regimes on viability of Gulf sturgeon populations. Trans Am Fish Soc. 2009;138: 1266-1284. https://doi.org/10.1577/T08-144.1

129. Price DM, Quinn T, Barnard RJ. Fish passage effectiveness of recently constructed road crossing culverts in the Puget Sound region of Washington State. North Am J Fish Manag. 2010;30: 1110-1125. https://doi.org/10.1577/M10-004.1

130. Gibson RJ, Haedrich RL, Wernerheim CM. Loss of fish habitat as a consequence of inappropriately constructed stream crossings. Fisheries. 2005;30: 10-17. https://doi.org/10.1577/1548-8446(2005)30[10:LOFHAA]2.0.CO;2

131. MacPherson LM, Sullivan MG, Lee Foote A, Stevens CE. Effects of culverts on stream fish assemblages in the Alberta Foothills. North Am J Fish Manag. 2012;32: 480-490. https://doi.org/10.1080/02755947.2012.686004

132. Maitland BM, Poesch M, Anderson AE, Pandit SN. Industrial road crossings drive changes in community structure and instream habitat for freshwater fishes in the boreal forest. Freshw Biol. 2016;61: 1-18. https://doi.org/10.1111/fwb.12671

133. Kime DE. The effects of pollution on reproduction in fish. Rev Fish Biol Fish. 1995;5: 52-95. https://doi.org/10.1007/BF01103366

134. Arp CD, Whitman MS, Kemnitz R, Stuefer SL. Evidence of hydrological intensification and regime change from northern Alaskan watershed runoff. Geophys Res Lett. 2020;47: e2020GL089186. https://doi.org/10.1029/2020GL089186

135. Dunham JB, Vinyard GL, Rieman BE. Habitat fragmentation and extinction risk of Lahontan Cutthroat Trout. North Am J Fish Manag. 1997;17: 1126-1133. https://doi.org/10.1577/1548-8675(1997)017<1126:HFAERO>2.3.CO;2 
Leppi et al. PLOS ONE 27 October 2021

1103

1104

1105

1106

1107

1108

1109

1110

1111

1112

1113

1114

1115

1116

1117

1118

1119

1120

1121

1122

1123

1124

1125

1126

1127

1128

1129

1130

1131

1132

1133

1134

1135
136. Edge CB, Fortin M-J, Jackson DA, Lawrie D, Stanfield L, Shrestha N. Habitat alteration and habitat fragmentation differentially affect beta diversity of stream fish communities. Landsc Ecol. 2017;32: 647-662. https://doi.org/10.1007/s10980-016-0472-9

137. Dias MS, Tedesco PA, Hugueny B, Jézéquel C, Beauchard O, Brosse S, et al. Anthropogenic stressors and riverine fish extinctions. Ecol Indic. 2017;79: 37-46. https://doi.org/10.1016/j.ecolind.2017.03.053 
Leppi et al. PLOS ONE 27 October 2021

\section{Supporting information}

1137

1138

1139

1140

1141

1142

1143

1144

1145

1146

1147

1148

1150

1151

1152

1153

1154

1155

1156

1157

1158

4

6

S1 Table. Summary of Broad Whitefish sampled. Table displaying population sex, age, and size structure, tissues sampled, and sample size for Broad Whitefish (Coregonus nasus) caught at three locations within the Colville River watershed, Alaska, USA.

\section{S2 Table. Laser Ablation System (LA) multi collector inductively coupled plasma mass} spectrometer (MC-ICP-MS) instrument parameters. Table displaying the LA MC-ICP-MS instrument parameters used at the Alaska Stable Isotope Facility, University of Alaska Fairbanks, Fairbanks, AK, USA.

S3 Table. Summary of Broad Whitefish (Coregonus nasus) sampled in the Colville River, AK, USA. Table displaying otoliths analyzed and attributes.

S1 Figure. Sr otolith plots. Plots showing ${ }^{88} \mathrm{Sr}$ concentration and ${ }^{87} \mathrm{Sr} /{ }^{86} \mathrm{Sr}$ for all Broad Whitefish (Coregonus nasus) caught within the Colville River watershed, Alaska, USA. We cropped strontium data for otoliths analyzed $(n=61)$ at the otolith core and edge.

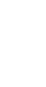

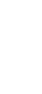




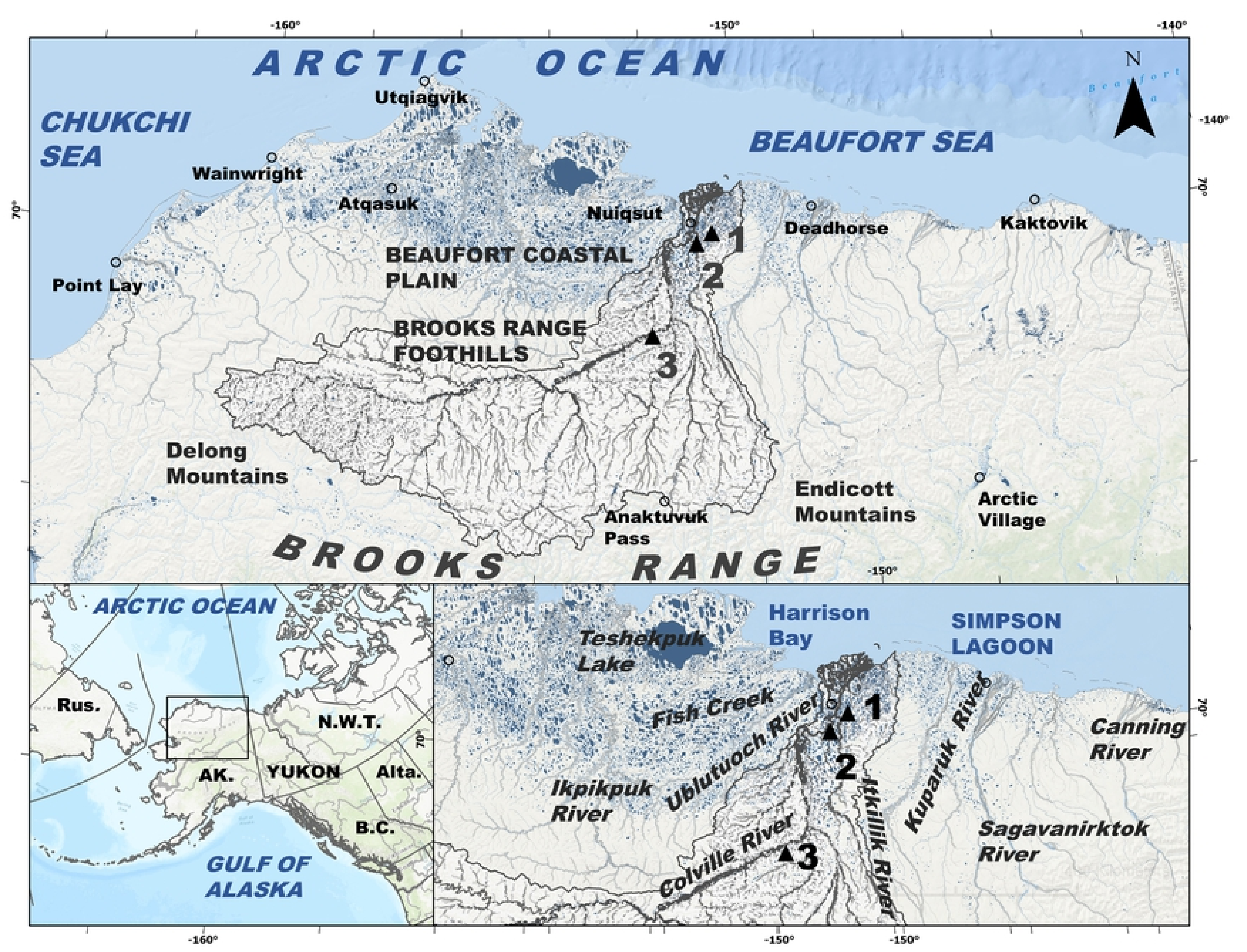

Fig 1 
A

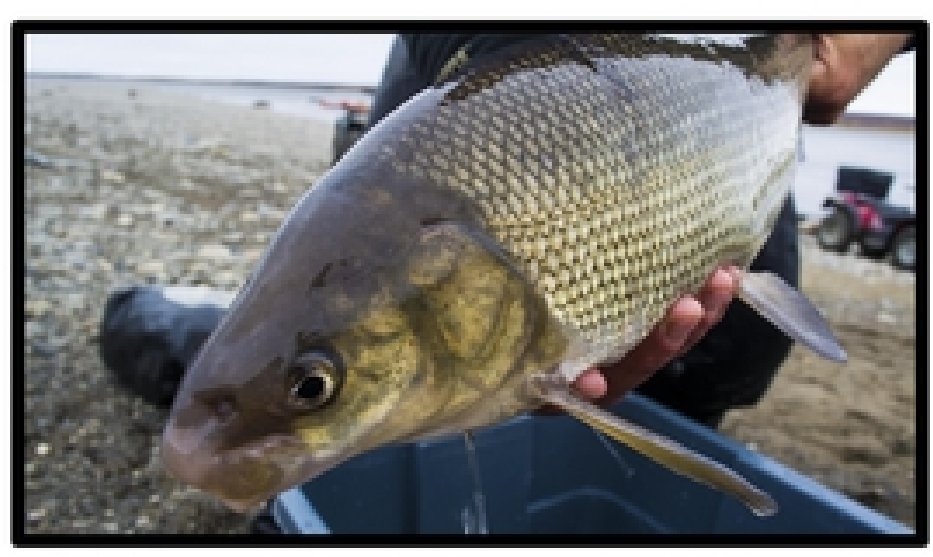

B

Age 13 Proximal

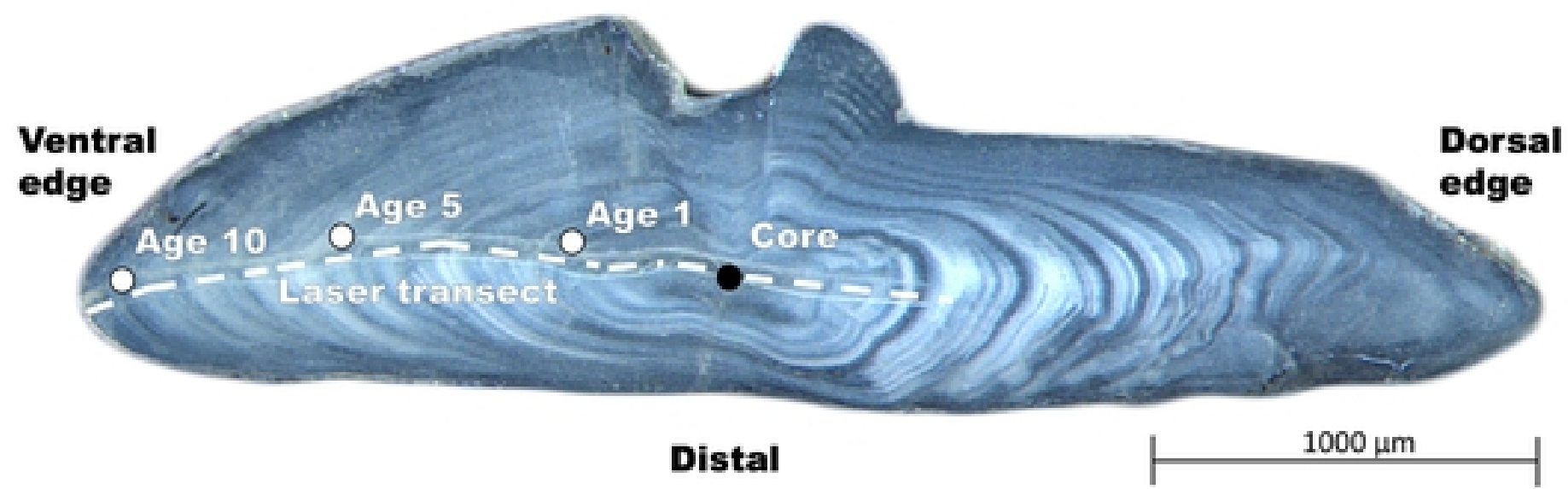

C

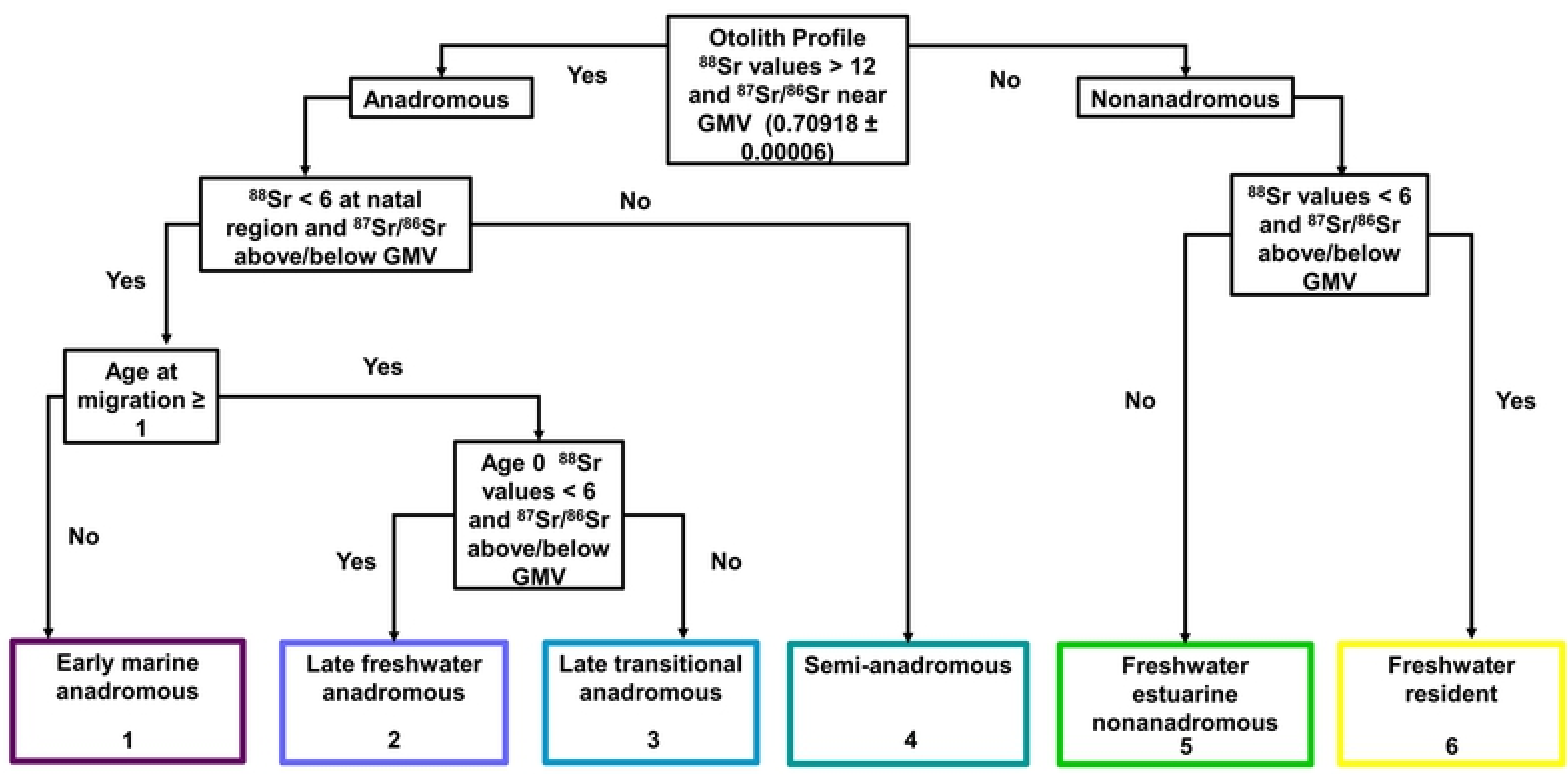

Fig 2 


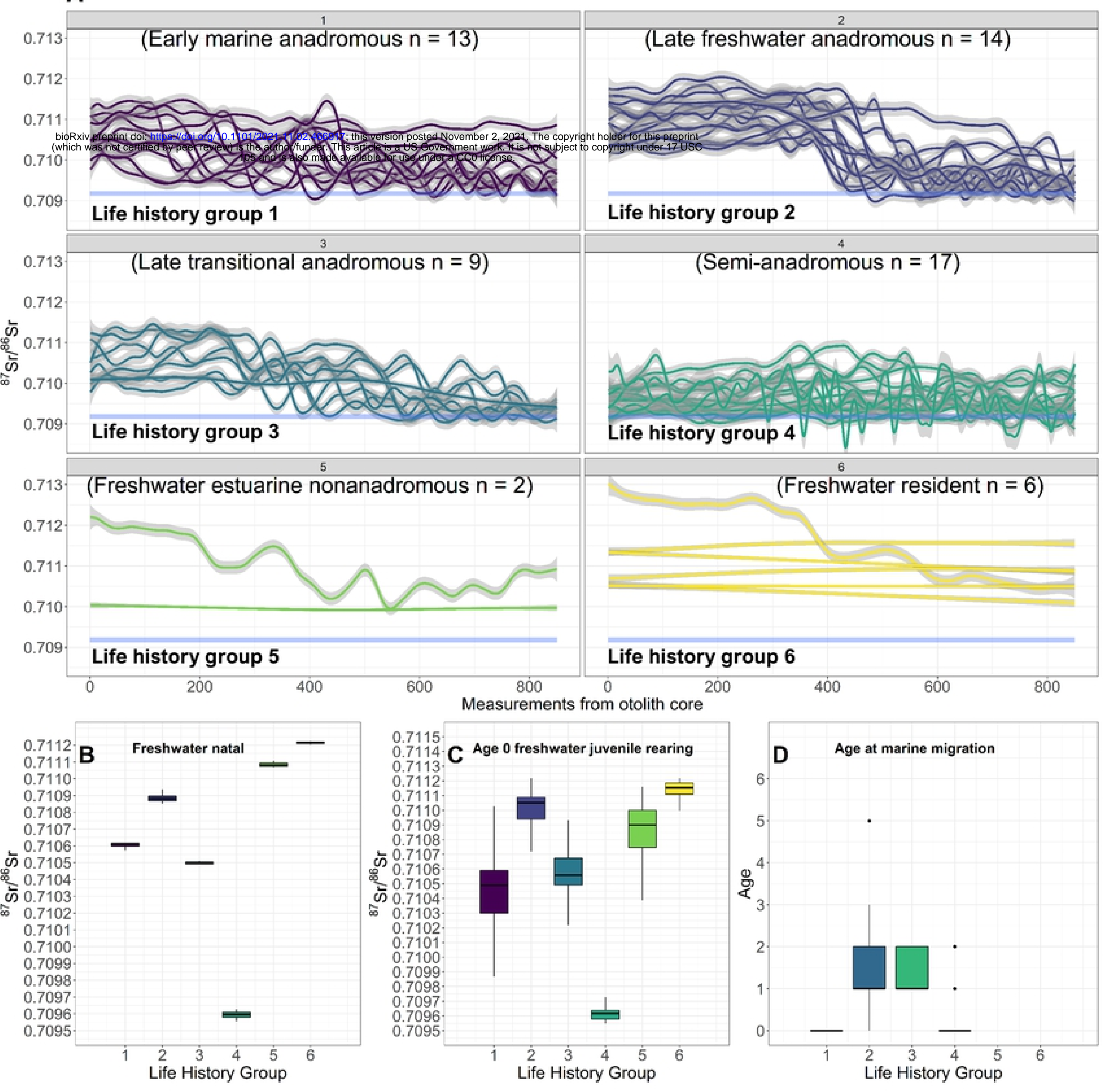

Fig 3 

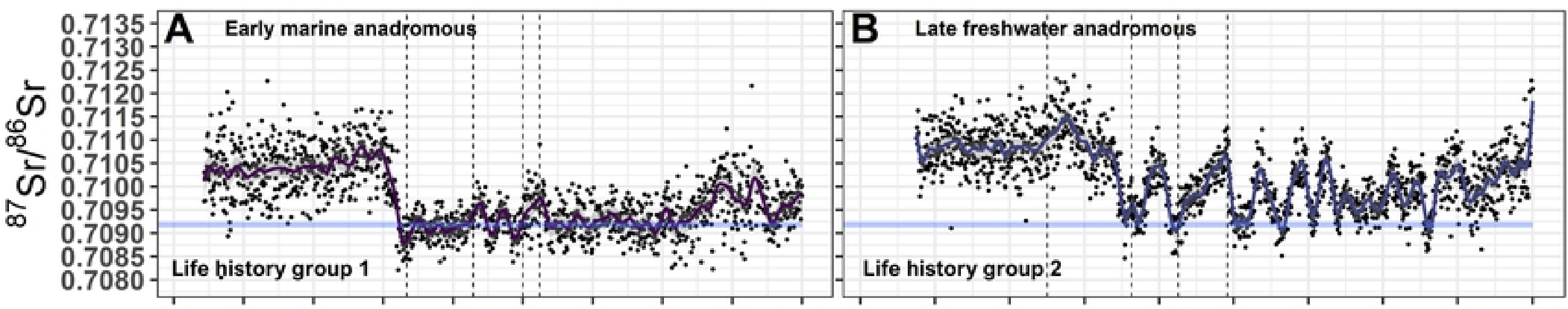

$\begin{array}{lllllllllllllllllll}10 & 20 & 30 & 40 & 50 & 60 & 70 & 80 & 90 & 10010 & 20 & 30 & 40 & 50 & 60 & 70 & 80 & 90 & 100\end{array}$
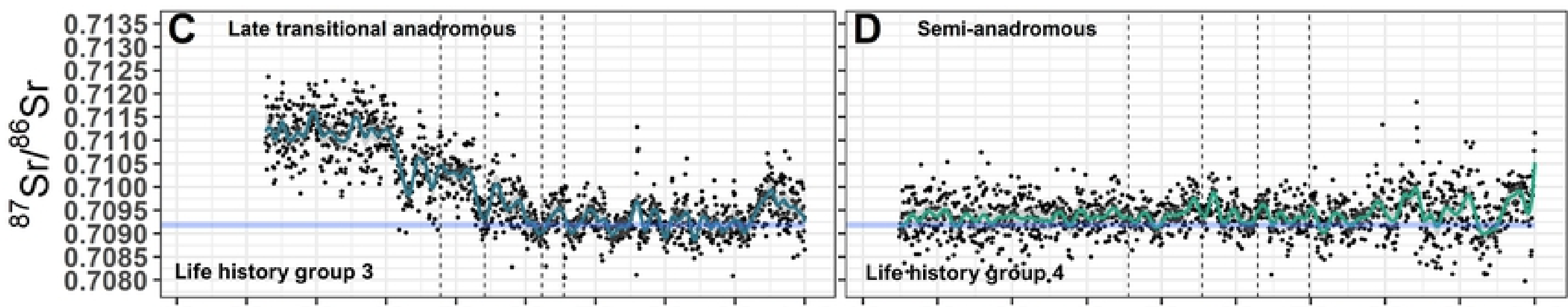

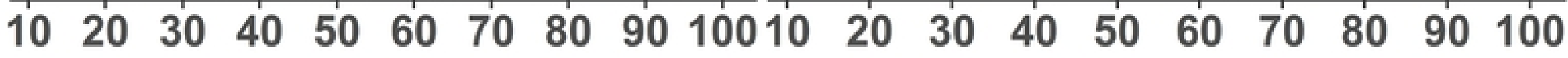
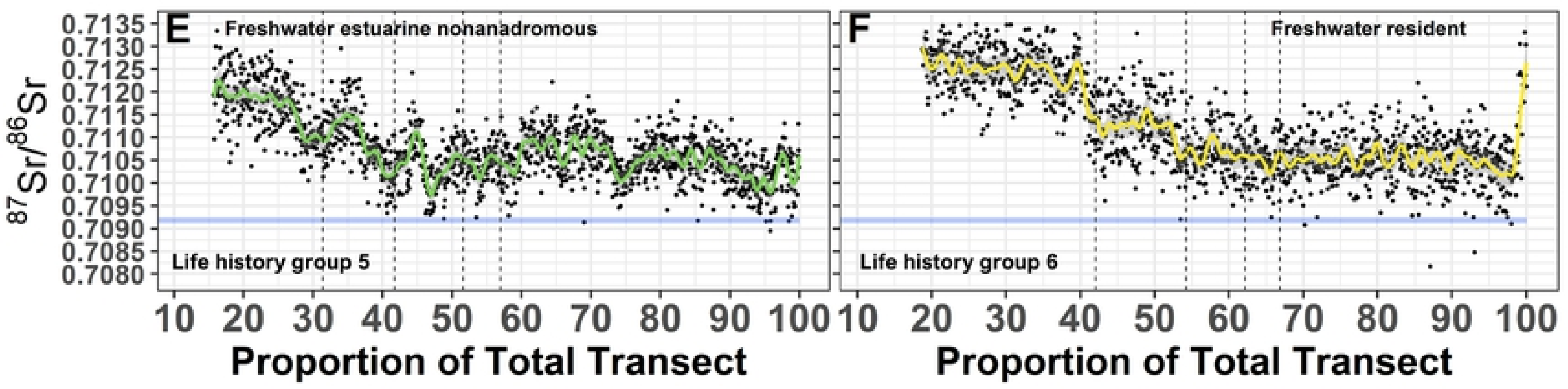

Fig 4 

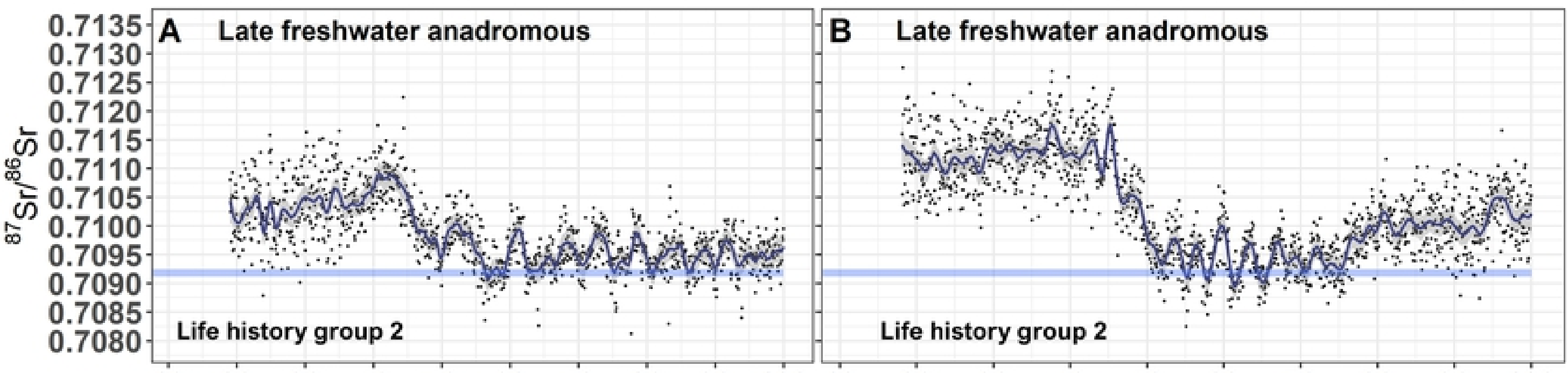

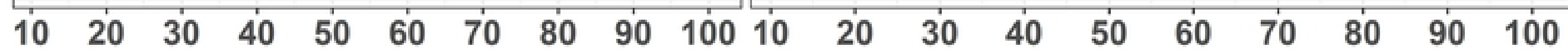

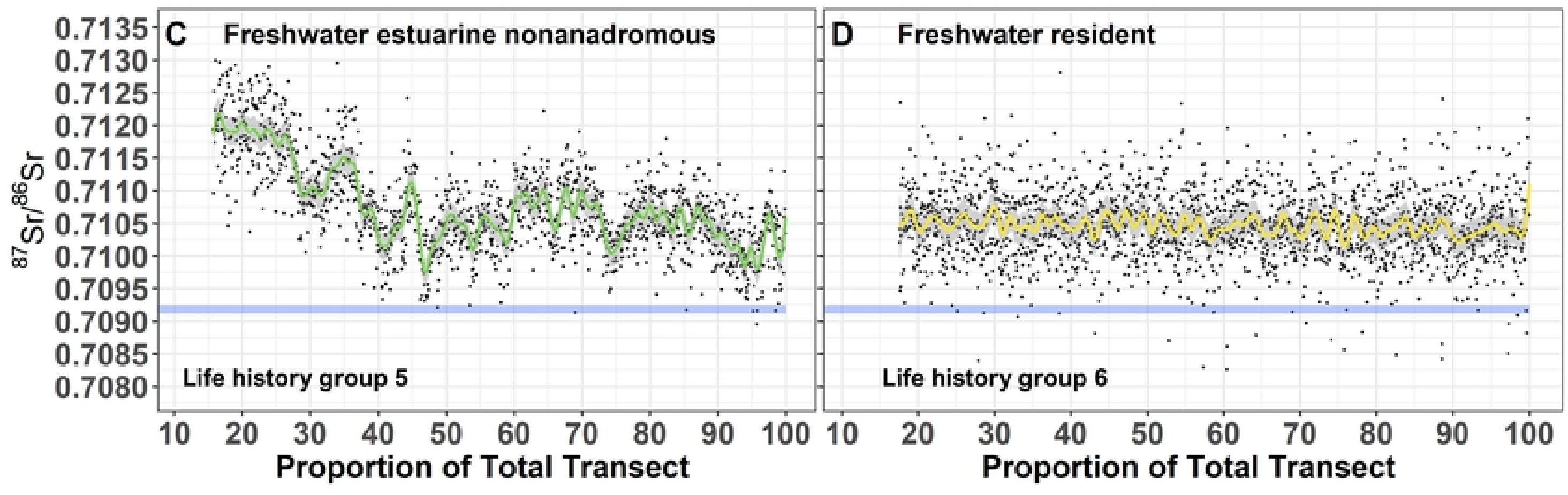

Fig 5 